\title{
Cooling rates of pyroclastic deposits inferred from mineral magnetic investigations: a case study from the Pleistocene Mýtina Maar (Czech Republic)
}

\author{
Philipp Lied $^{1} \cdot$ Agnes Kontny $^{2} \cdot$ Norbert Nowaczyk $^{3} \cdot$ Jan Mrlina ${ }^{4} \cdot$ Horst Kämpf $^{5}$
}

Received: 14 February 2019 / Accepted: 11 April 2020 / Published online: 13 May 2020

(c) The Author(s) 2020

\begin{abstract}
Tephra layers of the Mýtina Maar, Czech Republic, contain ferrimagnetic Mg-Al-rich titanomagnetite, which is suggested to originate from a fractionated alkaline $\mathrm{CO}_{2}$-rich lithospheric mantle melt. We investigated the magnetic mineralogy and Curie temperature $\left(T_{\mathrm{C}}\right)$ from tephra deposits of two drill cores $\left(<9 \mathrm{~m}\right.$ depth). $T_{\mathrm{C}}$ calculated $\left(208 \pm 14{ }^{\circ} \mathrm{C}\right)$ from chemical composition $\left(\mathrm{Fe}^{2+}{ }_{0.8} \mathrm{Mg}_{0.5} \mathrm{Fe}^{3+}{ }_{1.1} \mathrm{Al}_{0.3} \mathrm{Ti}_{0.3} \mathrm{O}_{4}\right)$ is in accordance with $T_{\mathrm{C}}$ retrieved from cooling curves of temperature-dependent magnetic susceptibility measurements $\left(195-232{ }^{\circ} \mathrm{C}\right)$. However, thermomagnetic curves are irreversible either with lower (type I) or higher (type II) $T_{\mathrm{C}}$ in the heating curve. All curves show transition temperatures above ca. $390{ }^{\circ} \mathrm{C}$, indicating maghemitization. We interpret the irreversibility of $T_{\mathrm{C}}\left(\Delta T_{\mathrm{C}}\right)$ in terms of different degrees of cation ordering, overprinted or masked by different degrees of maghemitization, which is a low-temperature phenomenon. Negative $\Delta T_{\mathrm{C}}$ indicates that original deposited titanomagnetite has cooled faster and, therefore, has stored a lower degree of cation ordering compared to heating/cooling rate of $11^{\circ} \mathrm{C} / \mathrm{min}$ in the Kappabridge. Type II with positive $\Delta T_{\mathrm{C}}$ indicates higher degree of cation ordering, and, therefore, slower cooling rate. The central part of this deposit shows most severe maghemitization, indicating rather wet emplacement. We, therefore, suggest different eruption styles for deposition of type I pyroclastics with more phreatomagmatic and type II pyroclastics with more phreato-Strombolian eruption styles. Our study is a new approach to discriminate different cooling histories in maar deposits using the Curie temperature of titanomagnetite. We suggest that this method has the potential to discriminate different emplacement modes resulting from different eruption styles.
\end{abstract}

Keywords Eger rift system - Maar-diatreme volcano - Titanomagnetite Curie temperature $\cdot$ Cation ordering effect . Maghemitization · Pyroclastic emplacement mechanism

Electronic supplementary material The online version of this article (https://doi.org/10.1007/s00531-020-01865-1) contains supplementary material, which is available to authorized users.

Philipp Lied

philipp.lied@kit.edu

1 Institute for Applied Materials-Applied Materials Physics, Karlsruhe Institute of Technology,

76344 Eggenstein-Leopoldshafen, Germany

2 Division of Structural Geology, Institute of Applied Geosciences, Karlsruhe Institute of Technology, Karlsruhe, Germany

\section{Introduction}

Maar-diatreme volcanoes are the product of a series of small-volume subsurface phreatic, phreatomagmatic, and/ or phreato-Strombolian eruptions (Lorenz and Kurszlaukis 2007; Ross and White 2012; Németh and Kereszturi 2015; Valentine et al. 2017; Ort et al. 2018). Fine-grained ejecta deposited during explosive eruptions are either deposited

3 Section Climate Dynamics and Landscape Evolution, German Research Centre for Geosciences GFZ Potsdam, Telegrafenberg, 14473 Potsdam, Germany

4 Institute of Geophysics, Czech Academy of Sciences, Boční II, 14131 Praha 4, Czech Republic

5 Section Organic Geochemistry, German Research Centre for Geosciences GFZ Potsdam, Telegrafenberg, 14473 Potsdam, Germany 
by pyroclastic flows close to the volcano or by ash clouds drifted laterally by wind. Therefore, explosive eruptions produce flow and fall deposits depending on the mode of transport and deposition (e.g., Schumacher and Schmincke 1995). The emplacement temperature of pyroclastic deposits is one of the most hazardous factors of the eruption conditions for people and infrastructures in the vicinity of volcanic structures (Baxter et al. 1998, 2017). The inferred deposition temperatures of pyroclastic deposits retrieved from the various proxies range from 100 up to $800^{\circ} \mathrm{C}$, with most common values around $250-370{ }^{\circ} \mathrm{C}$ (Giordano et al. 2018). One example is the 1977 Ukinrek Maar eruption showing a range from $805{ }^{\circ} \mathrm{C}$ in deposits of the phreato-Strombolian eruptive phase to $>100{ }^{\circ} \mathrm{C}$ in deposits of the phreatomagmatic eruptive phase (Kienle et al. 1980; Ort et al. 2018). This observation implies that-with a given chemistry of the erupting material-several factors like, e.g., the expansion of gases, a rapid deposition of material, or the distance of deposition to the source vent play a significant role for the emplacement temperature.

The distinction between "hot" (magmatic) and "cold" (phreatomagmatic) deposits is crucial, because the efficiency of the magma-water interaction and the loss of thermal energy during the phreatomagmatic eruption can be estimated (Porreca et al. 2006; Trolese et al. 2017; Giordano et al. 2018). Low-grade carbonization of wood fragments gave evidence for a low emplacement temperature of about $180-270{ }^{\circ} \mathrm{C}$ for poorly sorted lapilli tuffs and tuff breccia from the Mt. Gambier volcanic complex, Australia (van Otterloo and Cas 2016). Giordano et al. (2018) reported emplacement temperature between about 190 and $300{ }^{\circ} \mathrm{C}$ within an AD79 Vesuvius pyroclastic density current deposit (Herculaneum/Italy), using thermal remanent magnetization and reflectance of charcoal fragments. During phreatomagmatic eruptions, a large amount of thermal energy is dissipated and partially converted into kinetic energy. This rapid cooling mechanism might also have an influence on the cation ordering in titanomagnetite. Recent studies suggest that time- and temperature-dependent cation ordering in titanomagnetite might have the potential to provide a new application for geospeedometry in volcanic rocks. Up to now, this effect is well documented only in pyroclastic deposits from Plinian-type eruptions of Mt. St. Helens (Washington State, USA) and from Novarupta (Alaska) (Bowles et al. 2013, 2018; Jackson and Bowles 2014).

Titanomagnetite is one of the most common ferrimagnetic minerals in mafic rocks. Basically, the ferrimagnetism of the inverse titanomagnetite $\left(\mathrm{Fe}_{3-\mathrm{x}} \mathrm{Ti}_{\mathrm{x}} \mathrm{O}_{4}\right)$, solid solution series with magnetite $(x=0)$, and ulvöspinel $(x=1)$ as end members arises from the antiferromagnetic coupling of $\mathrm{A}$ and $\mathrm{B}$ sublattices with $\mathrm{Fe}^{3+}$ and $\mathrm{Fe}^{2+}$ cations on tetrahedral A sites and $\mathrm{Fe}^{3+}, \mathrm{Fe}^{2+}$, and $\mathrm{Ti}^{4+}$ cations on octahedral B sites. Magnetic properties like saturation magnetization, magnetic susceptibility, and Curie temperature $\left(T_{\mathrm{C}}\right)$ depend on the chemical composition of titanomagnetite (e.g., $T_{\mathrm{C}}$ ranges between 580 and $-153^{\circ} \mathrm{C}$ for magnetite and ulvöspinel, respectively), but it is also reported that $T_{\mathrm{C}}$ depends on vacancy concentration and cation ordering (Lattard et al. 2006; Bowles et al. 2013 and references therein). In pure magnetite $\left(\mathrm{Fe}_{3} \mathrm{O}_{4}\right)$, cation order/disorder only affects the $\mathrm{Fe}^{2+}$ and $\mathrm{Fe}^{3+}$ cation distribution on the octahedral sites (on tetrahedral sites, only $\mathrm{Fe}^{3+}$ is present). Therefore, different quenching histories give the same $T_{\mathrm{C}}$, and $T_{\mathrm{C}}$ from laboratory heating and cooling runs are reversible. This is not the case for synthetic magnesioferrite $\left(\mathrm{MgFe}_{2} \mathrm{O}_{4}\right)$ (Harrison and Putnis 1999) and for synthetic titanomagnetite (Lattard et al. 2006). These studies rather suggested that either cation vacancies or interactions of magnetic and cation ordering have an influence on $T_{\mathrm{C}}$. Jackson and Bowles (2014) documented for the first time significant irreversibility of $T_{\mathrm{C}}$ from pumice and ash flow samples of the Mt. St. Helens volcano, and argued that this irreversibility might enable the quantification of emplacement temperatures or cooling rates of volcanic units containing homogeneous titanomagnetite.

Although, in principle, the cation distribution varies with temperature and at high-temperature cation ordering is randomized, the cation distribution is complicated by its dependence on time, temperature, and thermodynamic stability due to oxygen fugacity, composition, and cation site occupancy (e.g., Sauerzapf et al. 2008; Lattard et al. 2012; Bowles et al. 2013). Despite these uncertainties, Bowles et al. (2013) have shown that $T_{\mathrm{C}}$ of homogeneous titanomagnetite in pyroclastic flows is strongly influenced by the thermal history around the $T_{\mathrm{C}}$ for $\mathrm{Ti}, \mathrm{Mg}$, and Al-bearing titanomagnetite. This observation implies that caution is required, if $T_{\mathrm{C}}$ is used to estimate the composition of titanomagnetite in such lithologies, and that not only secondary processes like hightemperature oxidation and maghemitization change $T_{\mathrm{C}}$, but also the degree of cation ordering during its primary cooling history.

In this study, we investigated tephra layers of the Mýtina Maar, Czech Republic (Mrlina et al. 2007, 2009), from two drill cores with a length of up to $9 \mathrm{~m}$ (Figs. 1, 2), using the analysis of $\mathrm{Fe}-\mathrm{Ti}$ oxide mineral assemblages and their magnetic properties. The tephra layers are characterized by enhanced magnetic susceptibility related to the titanomagnetite-bearing juvenile component of the deposits (Flechsig et al. 2015). We applied thermomagnetic measurements to elucidate the cooling history of the deposits. To our knowledge, this is the first study using the temperature-dependent cation ordering effects to infer cooling history of maar deposits. 

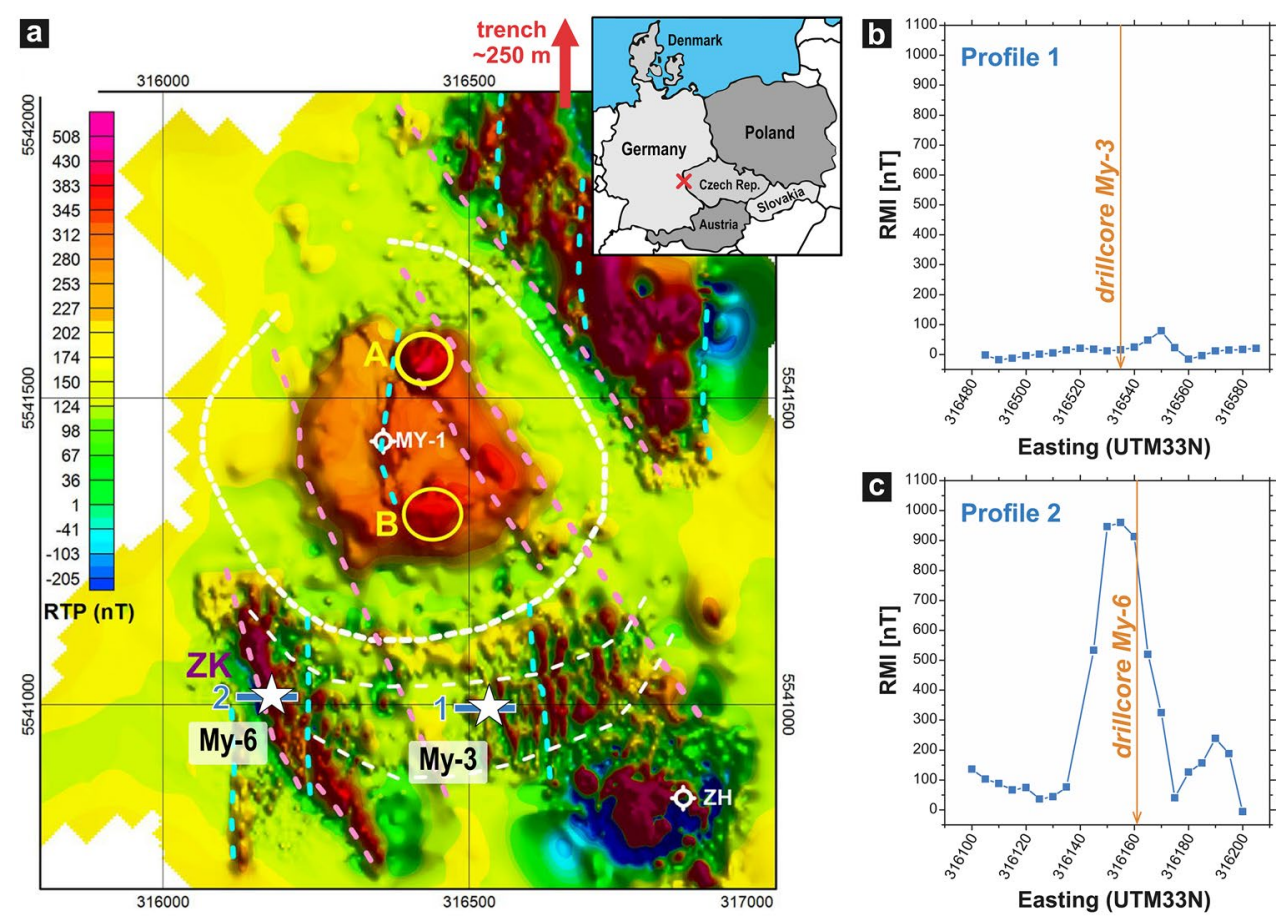

Fig. 1 a Reduced-to-pole (RTP) residual magnetic field intensity map of the Mýtina Maar with the central maar anomaly with position of drill cores My-3 (coordinates, easting: 316,535, northing: 5,541,005) and My-6 (coordinates, easting: 316,161, northing: 5,541,055), white stars, which were sampled for this study; ZK: Završský kout, MY-1: position of a 86.6 m-deep drill site at the Mýtina maar centre, $\mathrm{ZH}$ : Železná hůrka, A, B: central magnetic maar anomalies; white hashed line indicates morphological rim of the maar; pink and cyan hashed lines indicate NNW-SSE and N-S-trending magnetic zones; red

\section{Geodynamic setting and previous investigations}

In the last decade, the two Pleistocene maar-diatreme volcanoes Mýtina (Mrlina et al. 2009; Flechsig et al. 2015) and Neualbenreuth (Rohrmüller et al. 2018) were discovered in the western Eger Rift area by geological and geophysical surveys and subsequent drill-core sampling (Figs. 1, 2). The western part of the WSW-ENE-trending Eger Rift, particularly the Cheb Basin, which formed along NNW-SSEtrending faults (Špičáková et al. 2000; Rojik et al. 2014), is at present the most active geodynamic region in the European Cenozoic Rift System (ECRIS) with a high number of earthquake swarms at least in the last 40 years (Fischer et al. 2014; Vavryčuk and Adamová 2018) as well as mantlederived $\mathrm{CO}_{2}$-degassing (Weinlich et al. 1999; Bräuer et al. 2009, 2014; Kämpf et al. 2013, 2019; Nickschick et al. 2015). The progressive increase of the $\mathrm{He}^{3} / \mathrm{He}^{4}$ ratio at the eastern part of the Cheb Basin since about 2000 with shorttime peaks up to $6.3 R_{\mathrm{a}}$ in 2000 and 2006 at the Bublák arrow gives approximate position of an excavation trench (Geissler et al. 2004) in the north-eastern tephra deposit (map modified from Flechsig et al. 2015, Fig. 4; for details, we refer to this article). b, c Profiles 1 and 2 of residual magnetic intensity (RMI) with location of drill cores. Horizontal axis in WGS84/UTM33N coordinates. Position marked in a. Note also the low amplitude for profile 1 at drill core My-3 $(<80 \mathrm{nT})$ compared to maximum RMI in profile 2 near My-6 (960 nT)

mofette indicates an ascent of less degassed magma (dyke intrusion) from the lithospheric mantle reservoir into the crust (Bräuer et al. 2009, 2018). These active regions in the north-east and east parts of the Cheb Basin are located only $15-30 \mathrm{~km}$ north of the Mýtina maar.

The centre of the Mýtina Maar is located about $600 \mathrm{~m}$ NW of the Železná hůrka scoria cone (Fig. 1), near the village Mýtina. The outer rim of the maar crater has a diameter of nearly $500 \mathrm{~m}$. Pleistocene lacustrine sediments with a thickness of up to $80 \mathrm{~m}$ were drilled within the crater, clearly indicating the existence of a former maar lake (Mrlina et al. 2009). Two types of pyroclastic maar deposits are described in Geissler et al. (2004), Mrlina et al. (2007), and Flechsig et al. (2015) for the Mýtina Maar pyroclastic deposits. A lower, consolidated tuff sequence is deposited on top of the fragmented and weathered phyllite basement. The tuff sequence is overlaid by an unconsolidated tephra deposit (Fig. 2). The tephra contains $19-45 \%$ juvenile components and shows a significant higher magnetic susceptibility than the tuff. Phyllite and quartzite makes about $90 \%$ of the tuff composition, which explains a significant lower magnetic 


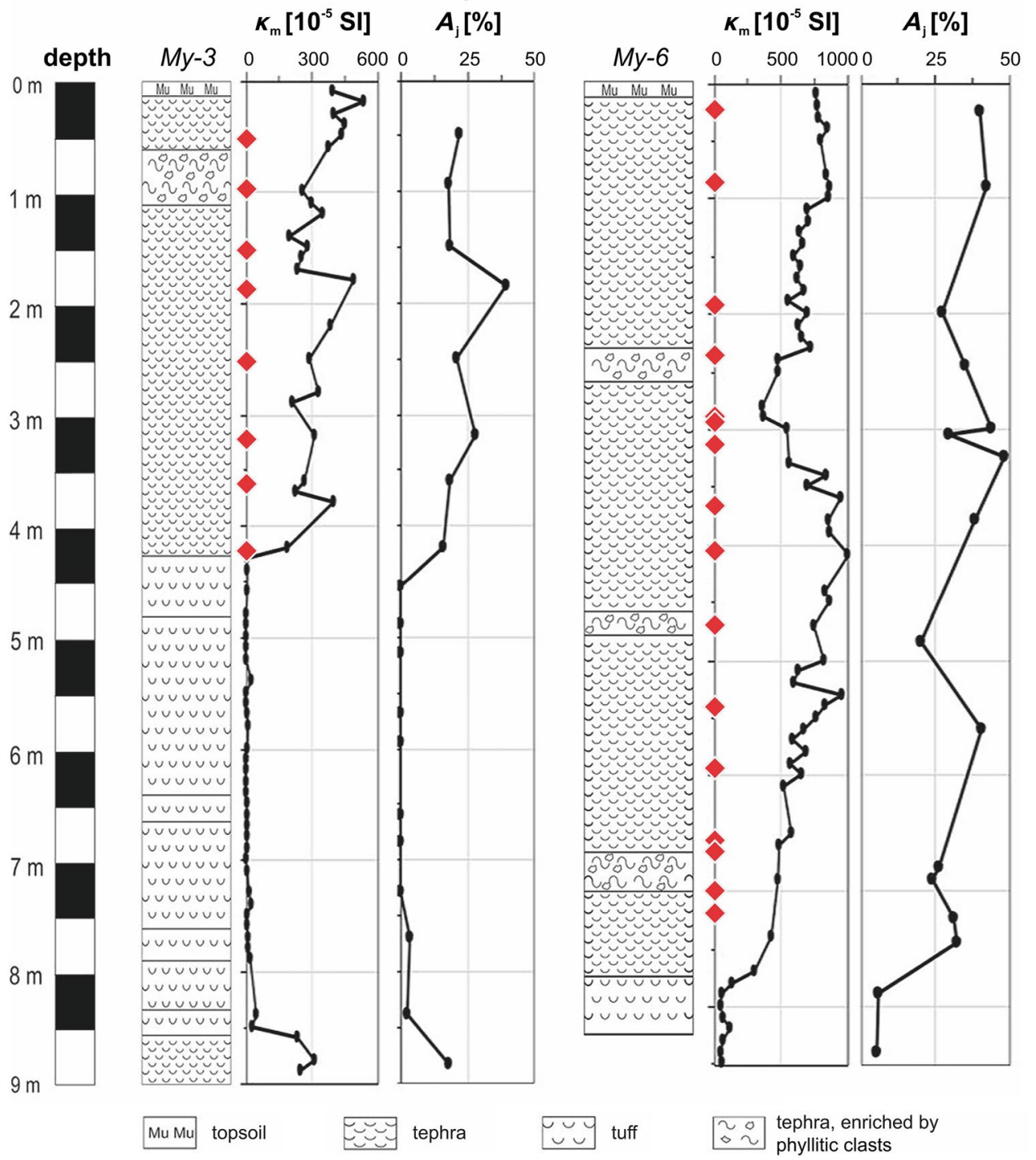

Fig. 2 Stratigraphic core description of drill cores My-3 and My-6 (Fig. 1) with magnetic susceptibility $\kappa_{\mathrm{m}}\left[10^{-5} \mathrm{SI}\right]$ and amount of magmatic juvenile proportion $A_{\mathrm{j}}[\%]$, determined from $\mathrm{TiO}_{2}, \mathrm{MgO}, \mathrm{CaO}$,

susceptibility. It is suggested that tuff and tephra deposits represent two different stages of the eruption (Flechsig et al. 2015).

Magnetic surveys, performed by the Institute of Geophysics in Prague in the vicinity of the Mýtina Maar, have shown a central magnetic anomaly related to the maar structure and another one to the Železná hůrka scoria cone (Fig. 1). In the surroundings of the crater, NNW-SSE and N-S oriented magnetic zones which indicate accumulations of volcanic rocks in the subsurface (Fig. 1). Shallow drill cores (My-1, My-2, My-3, and My-4) at the southern flank of the maar structure revealed tephra and underlying tuff deposits of several meters in thickness (Flechsig et al. 2015). The tephra
$\mathrm{P}_{2} \mathrm{O}_{5}, \mathrm{Sr}$, and $\mathrm{V}$ concentrations (modified from Flechsig et al. 2015). Note the higher scale of $\kappa_{\mathrm{m}}$ for My-6. Red diamonds indicate sample locations for magnetomineralogical investigations (Figs. 5, 6)

deposits show rapid thinning from $6 \mathrm{~m}$ at the edge of the maar (My-4) to $2.5 \mathrm{~m}$ at the periphery (My-1). Another core (My-6) was drilled into a $500 \mathrm{~m}$-long, NNW-SSE-trending magnetic anomaly at the SW flanks of the Mýtina Maar (Fig. 1). Immediate south and north of the Mýtina Maar, a large number of volcanic bombs can be found at surface (Flechsig et al. 2015, Fig. 6a). These bombs (up to $10 \mathrm{~cm}$ in size) are commonly of round shape.

According to Mrlina et al. (2009) and Brandl et al. (2015), whole-rock geochemical data of the Mýtina Maar juvenile components and the Železná hůrka scoria straddle the boundary between basanites and foidites. Because the volcanic glasses show higher concentrations of alkalis than 
the whole-rock samples, glasses can be classified as strongly $\mathrm{SiO}_{2}$-undersaturated foidites (Geissler et al. 2007; Brandl et al. 2015). Mineralogical and chemical investigations of mantle xenoliths, phenocrysts, and glass from tephra of the surrounding of the Mýtina maar and from Železná hůrka (Eisenbühl) provide evidence for mantle metasomatism of carbonate melt/peridotite interaction (Geissler et al. 2007; Ackerman et al. 2015).

The silica-undersaturated nephelinitic melts broke through crystalline schists of the Cheb Basin and its southern surrounding. Mrlina et al. (2007) determined an age of $288 \pm 17 \mathrm{ka}$ by $\mathrm{Ar}-\mathrm{Ar}$ dating for the juvenile component of the tephra from the Mýtina Maar. In addition to the two maar-diatreme volcanoes, the Pleistocene scoria cones Komorni hůrka (Kammerbühl) and Železná hůrka (Eisenbühl) are known to belong to this alkaline volcanic episode (Seifert and Kämpf 1994; Ulrych et al. 2013; Rapprich et al. 2019). At local scale, all the Pleistocene volcanic structures are located along the NNW-SSE-trending Tachov fault, a western segment of the Tachov-Domazlice Graben. At regional scale, the western Eger Rift is located near the intersection of three regional fault zones, the N-S-trending Regensburg-Leipzig-Rostock zone, the NNW-SSE directed Tachov-Domazlice Graben and the WSW-ENE-striking Eger Graben (Bankwitz et al. 2003; Geissler et al. 2004).

In this study, we present data from drill core My-3, with a tephra layer of about $4 \mathrm{~m}$ thickness in the south of the Mýtina Maar, and from drill core My-6, deepened in a tephra layer of about $8 \mathrm{~m}$ thickness in the south-western area with a linear magnetic anomaly (Figs. 1,2). Beside the tephra samples of the drill cores, two volcanic bombs are also included in this study (Bo1 and Bo3), which were sampled from the excavation trench (Fig. 1) in the northeastern tephra deposit (Geissler et al. 2004).

\section{Samples and methods}

\section{Samples and sample preparation}

Parts of the collected volcanic bombs (Bo1 and Bo3) were cut and either ground with an agate mill for $\kappa(T)$ measurements or used for thin-section preparation. The drill cores My-3 and My-6, consisting of tephra and brecciated country-rock, also were sampled (28 samples in total). If not fine-grained enough, these samples were crushed with an aluminium hammer to prevent contamination with ferromagnetic material. For later microscopic analysis of heated and $\kappa(T)$-measured samples, the coarse rock powder was embedded in resin, and then, polished sections were prepared.

\section{Optical and scanning electron microscopy with chemical analysis}

Transmitted and reflected light microscopy on thin sections was performed on Leitz polarisation microscopes at German Research Centre for Geoscience (GFZ, Potsdam) and Karlsruhe Institute of Technology (KIT). Scanning electron microscopy (SEM), back-scatter electron (BSE) imaging with acceleration voltage of $20 \mathrm{kV}$ (ZEISS Ultra Plus SEM), and initial mineral characterization by energydispersive X-ray (EDX) analysis and electron microprobe analysis (JEOL Hyperprobe JXA-8500F with $15 \mathrm{kV}$ ) were done at GFZ. For the latter, well-characterized natural and synthetic standards were used for calibration: chromia (Cr), diopside ( $\mathrm{Si}, \mathrm{Mg}$ ), ferric oxide ( $\mathrm{Fe})$, gahnite ( $\mathrm{Al})$, ilmenite (Ti), nickel monoxide ( $\mathrm{Ni})$, rhodonite $(\mathrm{Mn})$, and tugtupite (Na). Further investigations at KIT included BSE imaging (FEI Quanta FEG with $10 \mathrm{kV}$ ). Spinel formulae were calculated from cation and $\mathrm{Fe}_{2} \mathrm{O}_{3}$ content assuming stoichiometric composition in relation to anions (cation/anion $=3 / 4$ ).

\section{Rock magnetic analysis}

Initial magnetic characterization of temperature-dependent magnetic susceptibility $\kappa(T)$ was measured with an AGICO MFK1-A Kappabridge with a CS-3 unit for low-temperature measurements $\left(-196\right.$ to $\left.+15{ }^{\circ} \mathrm{C}\right)$ and for high-temperature measurements $\left(+25\right.$ to $\left.+700{ }^{\circ} \mathrm{C}\right)$ at GFZ, Potsdam. The applied magnetic field was $200 \mathrm{~A} / \mathrm{m}$. Further investigations were made with a KLY-4S Kappabridge equipped with a CS-L and CS-3 unit at KIT, and the applied magnetic field was $423 \mathrm{~A} / \mathrm{m}$. Cooling of the samples down to $-196{ }^{\circ} \mathrm{C}$ was done by liquid nitrogen in the cryostat with subsequently applied logarithmic heating rates (ca. $2.5^{\circ} \mathrm{C} / \mathrm{min}$ on average). The temperature was measured with a Pt resistance thermometer that was placed in contact with the crushed or powdered sample. According to the manufacturer of the resistance thermometer (JUMO), the recorded temperature values are accurate within $\pm 1^{\circ} \mathrm{C}$ at temperatures up to $150{ }^{\circ} \mathrm{C}$ but within $\pm 3{ }^{\circ} \mathrm{C}$ in the range of $150-700{ }^{\circ} \mathrm{C}$ (Lattard et al. 2006). For the high-temperature measurements, a constant argon flow in the furnace inside the thermostat minimised sample oxidation. Additionally, some samples where measured in ambient atmosphere for comparison. The heating and cooling rates from room temperature to $700{ }^{\circ} \mathrm{C}$ and back to $40^{\circ} \mathrm{C}$ were ca. $11^{\circ} \mathrm{C} / \mathrm{min}$.

Along with normal $\kappa(T)$-measurements, multiple stepwise heating-cooling cycles were made with one sample to better characterize the observed irreversible behaviour of titanomagnetite/titanomaghemite. Starting with $325^{\circ} \mathrm{C}$, the maximum temperature was raised for every cycle by $100{ }^{\circ} \mathrm{C}$ to a maximum of $825^{\circ} \mathrm{C}$. The Kappabridge (KLY-4) was configured to maintain the respective maximum temperature 
for $15 \mathrm{~min}$ to ensure that the sample is completely heated at each specific maximum temperature.

Determination of $T_{\mathrm{C}}$ from $\kappa(T)$-curves was done by the "peak method" (Lattard et al. 2006). Because the $T_{\mathrm{C}}$ corresponds to a second-order phase transition with a critical point at which the magnetic susceptibility is theoretically infinite, the $T_{\mathrm{C}}$ is estimated as a local maximum in $\kappa(T)$ curves (Petrovský and Kapička 2006; Lattard et al. 2006). Due to chemical inhomogeneities, many $\kappa(T)$-curves in the present study did not show a sharp peak followed by a steep drop of $\kappa$ right below the $T_{\mathrm{C}}$. Instead, the observed peak of titanomagnetite is broadened by a few ${ }^{\circ} \mathrm{C}$. In this case, the local maximum represents the $T_{\mathrm{C}}$ of titanomagnetite with average Ti content, where its transition to paramagnetic behaviour begins to dominate.

In case of transition temperatures for titanomaghemite decomposition with no clearly defined peak and very broad drops in susceptibility, the peak method cannot be applied. The same issue exists for observed drops in $\kappa(T)$ near the $T_{\mathrm{C}}$ of pure magnetite composition and the $\kappa(T)$-signal of this minor phase is dominated by presence of other magnetic oxide phases (e.g., Fig. 5b, $T_{\mathrm{C}} 3$ ). To circumvent these issues and to get comparable results, we approximated a transition temperature by the following geometrical method: a tangent is first aligned to the inflection point of the left uprising part of the $\kappa(T)$-curve. Then, a second tangent is aligned on the right falling part of the curve, forming a $\Lambda$-shape. The crossing point is interpreted as the approximated transition temperature. If this method is also applied for sharp peaks in $\kappa(T)$-curves, the result is equal to the result obtained from the peak method (see supplementary material). For very broad peaks, where no clear transition temperature can be derived, this method yields results that are internally consistent. Nevertheless, one should keep in mind that the given values in these cases are starting temperature for decomposition or randomization of magnetic moments. In our study, this approach allows us to compare the transition temperatures.

\section{Results}

\section{Geology and petrography of volcaniclastic rocks}

The volcanic deposits sampled by the up to 9 m-deep drill cores at the southern rim of the Mýtina Maar can be mainly subdivided into tuff and tephra (Flechsig et al. 2015). The lower tuff layers of the shallow drill cores show clasts of phyllite (with chlorite and muscovite), quartz phyllite, and mica schist with quartzite lenses with heterogeneous grain sizes. They represent the country rock. Accessory minerals are ilmenite and rutile. Fragments of juvenile magmatic material were microscopically not observed in these layers, which is in agreement with susceptibility measurements and geochemical studies (Flechsig et al. 2015). Because of the low ferrimagnetic mineral content, the tuff has shown not to be suited for further thermomagnetic investigations and will not be considered any further in this study.

Volcanic bombs and lapilli can be found in the upper tephra layers. These layers have the highest content of magmatic material and are a mixture of juvenile and countryrock material with grains from $\mu \mathrm{m}$ to $\mathrm{cm}$ sizes. The basanite fragments contain xenomorphic or hypidiomorphic phenocrysts of olivine and clinopyroxene, often with rounded or jagged grain boundaries, embedded in a microcrystalline matrix. Olivine is mostly fractured and occasionally shows symplectic overgrowth. Agglomerates of several olivine phenocrysts together with zoned $\mathrm{Cr}$-rich spinel represent xenolith fragments from the mantle. The matrix also contains fine-grained olivine, spinel phases, and twinned clinopyroxene, as well as accessory biotite/phlogopite. Vesicles are filled by zeolite. These observations are in line with results from Geissler et al. (2007). A summary of the mineralogical paragenesis in the magmatic material and the country rock is shown in Table 3, supplementary material.

\section{Texture and composition of spinel phases}

Oxide minerals from the Mýtina drill cores belong to the spinel-magnetite series. $\mathrm{Cr}-\mathrm{Al}-$ spinel cores are mantled by a more Al-rich spinel and rimmed by $\mathrm{Mg}-\mathrm{Al}$-rich titanomagnetite, which is also found as very fine-grained dispersed crystals in the matrix (Fig. 3a). Figure $3 \mathrm{c}$ shows a compositional profile and Table 1 gives mineral chemical analyses of the three distinguished spinel phases.

The $\mathrm{Cr}-\mathrm{Al}$-spinel cores have $\mathrm{Cr} \#(100 \times[\mathrm{Cr} /(\mathrm{Cr}+\mathrm{Al})])$ on average of $56.5 \%$ and high $\left.\mathrm{Mg} \#\left(100 \times \mathrm{Mg} /\left(\mathrm{Mg}+\mathrm{Fe}^{2+}\right)\right]\right)$ of $71.6 \%$, with only a slight change towards the rim of the core. Cr\# between 50 and $60 \%$ are typical for harzburgite mantle xenoliths (e.g., Haggerty 1991). Cr-Al-spinel is often intergrown with olivine and shows no Al-rich spinel mantle and $\mathrm{Mg}-\mathrm{Al}$-rich titanomagnetite rim at these intergrowth surfaces (Fig. 3a).

The Al-rich spinel mantle shows decreased Cr\# (37.7\%) and $\mathrm{Mg \#}(58.9 \%)$. While the $\mathrm{Cr} \#$ is in a relatively narrow range, the $\mathrm{Mg} \#$ and $\mathrm{Ti} \#(100 \times[2 \mathrm{Ti} /(2 \mathrm{Ti}+\mathrm{Al}+\mathrm{Cr})])$ show a large variation (Fig. 4a, b). In addition to a relatively high $\mathrm{TiO}_{2}$ concentration (on average $4.2 \mathrm{wt} \%$ ), this behaviour suggests a later modification of the spinel core composition either due to mantle metasomatism or infiltration of a new melt (e.g., Ackerman et al. 2015).

The $\mathrm{Mg}-\mathrm{Al}$-rich titanomagnetite rims and groundmass grains have the lowest $\mathrm{Cr} \#(37.7 \%)$ and $\mathrm{Mg \#} \mathrm{(58.9 \% ),} \mathrm{but}$ show a large variation in Cr\#. They are characterized by $\mathrm{Ti}$ content of 0.29 cations per formula unit (cpfu), $\mathrm{Al}$ content of $0.29 \mathrm{cpfu}$, and $\mathrm{Mg}$ content of $0.49 \mathrm{cpfu}$ in average. The 
$\mathrm{Cr}, \mathrm{Al}, \mathrm{Mg}$, and $\mathrm{Mn}$ concentration is $0.81 \mathrm{cpfu}$ in average (standard deviation of 0.05).

Interestingly, the Al-rich spinel mantle shows clear resorption features by $\mathrm{Mg}-\mathrm{Al}$-rich titanomagnetite, suggesting a changing residual magma composition. The Mg-Alrich titanomagnetite composition, therefore, suggests a more fractionated alkaline $\mathrm{CO}_{2}$-rich melt (e.g. Haggerty 1991; Ackerman et al. 2015). These Mg-Al-rich titanomagnetites, which occur as rims around spinel and as tiny grains in the groundmass, represent the only ferrimagnetic phase in the magmatic rocks and are responsible for the observed magnetic anomalies around the Mýtina Maar (Fig. 1).

Calculation of the ulvöspinel content $(x)$ for all analyzed $\mathrm{Mg}-\mathrm{Al}$-rich titanomagnetite grains and rims show values between 0.27 and 0.35 . Using only the ulvöspinel component of titanomagnetite for calculating the Curie temperature $\left(T_{\mathrm{C}}\right)$
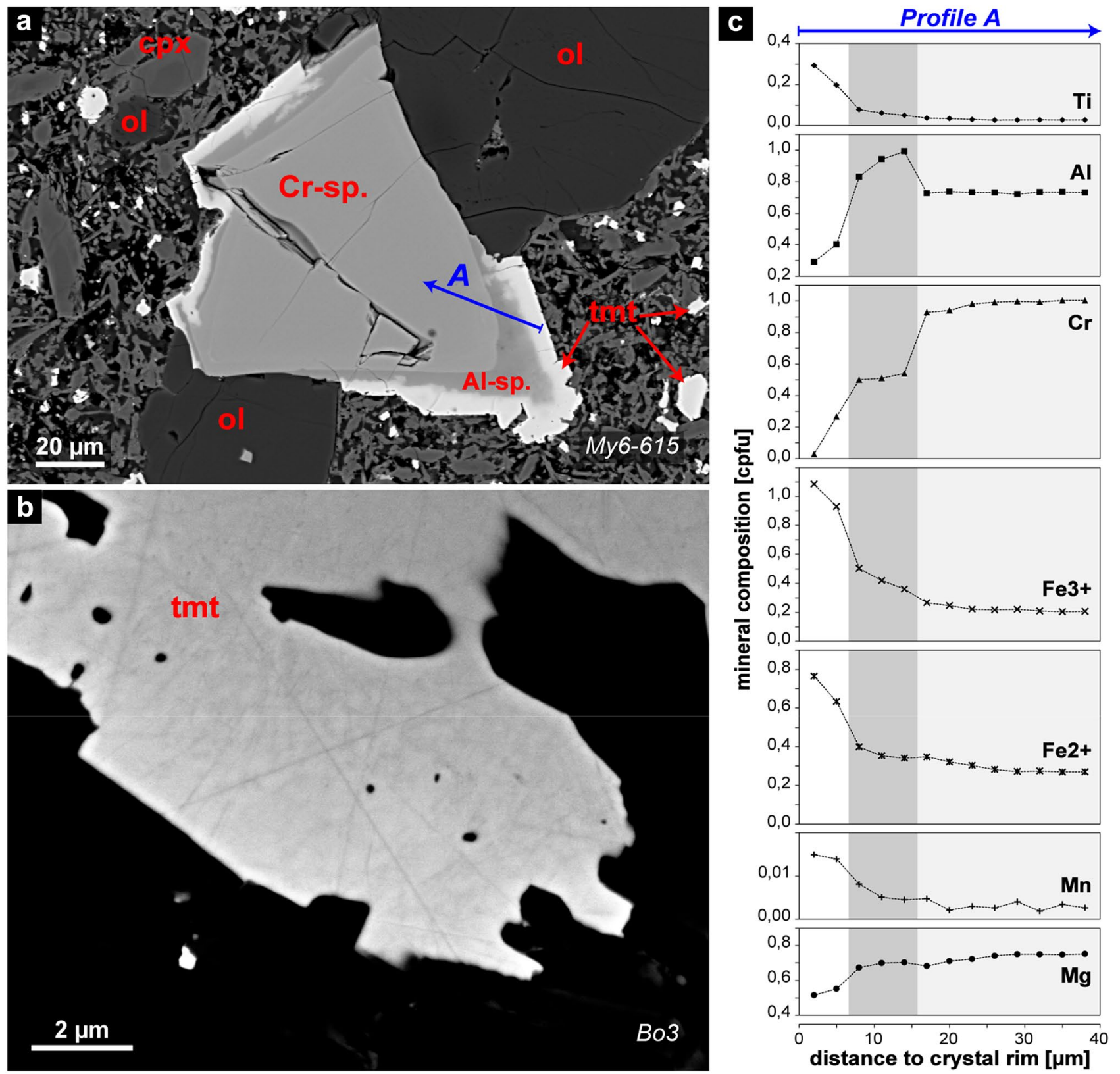

Fig. 3 a BSE imaging of the magmatic matrix with $\mathrm{Cr}$-spinel, surrounded by Al-rich spinel and titanomagnetite (tmt, very bright) and often intergrown with larger olivine (ol) crystals (dark grey). The fine-grained matrix is dominated by olivine, clinopyroxene (cpx) and also tmt. b Detailed BSE imaging of tmt rim with high-contrast
SEM settings reveals a fine mottled substructure of tmt. The observed features are consistent for sampled tephra and volcanic bombs. c Profile of microprobe chemical analysis of the zoned spinel border in a with grey shadings marking the transition from tmt (bright) to Al-sp (grey) and to $\mathrm{Cr}$-sp (light grey) 
Table 1 Results of electron microprobe analysis on the three observed spinel phases found in the magmatic fraction of the tephra and volcanic bombs

\begin{tabular}{|c|c|c|c|c|c|c|}
\hline & \multicolumn{2}{|l|}{$\mathrm{Cr}-$ spinel } & \multicolumn{2}{|c|}{ Al-spinel } & \multicolumn{2}{|l|}{ tmt } \\
\hline & Average & SD & Average & SD & Average & SD \\
\hline $\mathrm{n}$ & 59 & & 35 & & 83 & \\
\hline $\mathrm{SiO}_{2}$ & 0.119 & 0.092 & 0.126 & 0.104 & 0.225 & 0.438 \\
\hline $\mathrm{TiO}_{2}$ & 1.259 & 0.188 & 4.209 & 2.302 & 11.431 & 0.459 \\
\hline $\mathrm{Al}_{2} \mathrm{O}_{3}$ & 21.312 & 1.317 & 21.439 & 6.745 & 7.323 & 0.490 \\
\hline $\mathrm{Cr}_{2} \mathrm{O}_{3}$ & 41.328 & 2.104 & 19.629 & 6.453 & 0.624 & 0.887 \\
\hline $\mathrm{FeO}$ & 19.553 & 2.156 & 38.722 & 11.846 & 66.983 & 1.397 \\
\hline $\mathrm{MgO}$ & 16.379 & 0.594 & 14.026 & 1.847 & 9.687 & 0.769 \\
\hline $\mathrm{MnO}$ & 0.099 & 0.032 & 0.297 & 0.136 & 0.581 & 0.096 \\
\hline $\mathrm{NiO}$ & 0.197 & 0.033 & 0.113 & 0.043 & 0.064 & 0.024 \\
\hline $\mathrm{Na}_{2} \mathrm{O}$ & 0.010 & 0.014 & 0.008 & 0.012 & 0.008 & 0.019 \\
\hline Total & 100.256 & & 98.569 & & 96.927 & \\
\hline $\mathrm{Si}$ & 0.004 & 0.003 & 0.004 & 0.003 & 0.008 & 0.015 \\
\hline $\mathrm{Ti}$ & 0.028 & 0.004 & 0.099 & 0.059 & 0.290 & 0.012 \\
\hline $\mathrm{Al}$ & 0.754 & 0.041 & 0.767 & 0.218 & 0.291 & 0.019 \\
\hline $\mathrm{Cr}$ & 0.982 & 0.055 & 0.471 & 0.143 & 0.017 & 0.024 \\
\hline $\mathrm{Fe}^{3+}$ & 0.201 & 0.030 & 0.556 & 0.237 & 1.098 & 0.036 \\
\hline $\mathrm{Fe}^{2+}$ & 0.290 & 0.028 & 0.452 & 0.117 & 0.791 & 0.042 \\
\hline $\mathrm{Mg}$ & 0.733 & 0.024 & 0.639 & 0.060 & 0.487 & 0.037 \\
\hline Mn & 0.003 & 0.001 & 0.008 & 0.004 & 0.017 & 0.003 \\
\hline $\mathrm{Ni}$ & 0.005 & 0.001 & 0.003 & 0.001 & 0.002 & 0.001 \\
\hline $\mathrm{Na}$ & 0.001 & 0.001 & 0.000 & 0.001 & 0.001 & 0.001 \\
\hline Total & 3.000 & & 3.000 & & 3.000 & \\
\hline $\mathrm{Mg \#}$ & 71.642 & 2.619 & 58.994 & 8.242 & 38.091 & 2.948 \\
\hline $\mathrm{Cr} \#$ & 56.537 & 2.483 & 37.789 & 2.886 & 4.693 & 5.770 \\
\hline Ti\# & 3.182 & 0.536 & 15.89 & 12.758 & 65.409 & 3.648 \\
\hline$T_{\mathrm{C} \text { Calc }(\mathrm{Al}, \mathrm{Cr}, \mathrm{Mg}, \mathrm{Mn})}$ & & & & & 207.8 & 14.3 \\
\hline
\end{tabular}

Values for oxide content are average of $\mathrm{n}$ measuring points from different samples and are given in wt $\%$ with standard deviation (SD). Average cation content given in cations per formula unit (cpfu) with SD.



according to the formula given in Engelmann (2008) and Lattard et al. (2006):

$T_{\text {C Calc }}=852.5 \mathrm{~K}-539.5 \mathrm{~K} \times x-204.5 \mathrm{~K} \times x^{2}$

the resulting $T_{\mathrm{C} \text { Calc }}$ are in the range of $370-420{ }^{\circ} \mathrm{C}$. These values are significantly higher than the measured ones for the homogeneous titanomagnetite of the Mýtina samples (172-264 ${ }^{\circ} \mathrm{C}$; see "Magnetic transition temperatures"), because by only taking Ti cations into account, the effect on $T_{\mathrm{C}}$ of other cation substitutions like $\mathrm{Al}$ and $\mathrm{Mg}$ is not considered (Dunlop and Özdemir 1997). It is known from studies on synthetic Al- and Mg-rich titanomagnetite (Ti content lower than $0.7 \mathrm{cpfu}$ ) that these cations lower the $T_{\mathrm{C}}$ in the empirical relation of formula (2) (Engelmann 2008). Assuming that $\mathrm{Cr}^{3+}$ ions in the titanomagnetite lattice behave in a similar way as $\mathrm{Al}^{3+}$, and $\mathrm{Mn}^{2+}$ similar as $\mathrm{Mg}^{2+}$, we can modify the equation to formula (3) (all element units in cpfu):
$T_{\mathrm{C} \text { Calc (Al,Mg) }}=T_{\mathrm{C} \mathrm{Calc}}-593 \times[\mathrm{Al}]-82 \times[\mathrm{Mg}]$

$T_{\mathrm{C} \text { Calc }(\mathrm{Al}, \mathrm{Cr}, \mathrm{Mg}, \mathrm{Mn})}=T_{\mathrm{C} \text { Calc }}-593 \times[\mathrm{Al}+\mathrm{Cr}]-82 \times[\mathrm{Mg}+\mathrm{Mn}]$

and receive $T_{\mathrm{C}}$ values in the range between 114 and $228^{\circ} \mathrm{C}$ with an average of $208^{\circ} \mathrm{C}$ (Table 1). Calculated $T_{\mathrm{C}}$ values show a rapid decrease below $-200{ }^{\circ} \mathrm{C}$ with changing composition from the $\mathrm{Mg}-\mathrm{Al}$-rich titanomagnetite towards the Al-rich spinel mantle with low Fe and Ti contents (Fig. 3c).

Although the Mg-Al-rich titanomagnetite looks homogeneous in reflected light microscopy, which is also supported by numerous microprobe analyses and the calculated low $T_{\mathrm{C}}$ values, scanning electron microscopy reveal a faint mottled texture (Fig. 3b), as the first indication of subtle alteration. 
Fig. 4 Variation of spinel compositions in the Mýtina drill-core tephra material. a $\mathrm{Mg} \#$ and $\mathrm{Cr} \#$ and $\mathbf{b} \mathrm{Mg \#}$ and $\mathrm{Ti} \#$ variation of all $\mathrm{Cr}-\mathrm{Al}-\mathrm{spi}$ nel cores, Al-rich spinel mantle, and $\mathrm{Mg}-\mathrm{Al}$-rich titanomagnetite (tmt) rims and groundmass analyses used for average calculations in Table 1

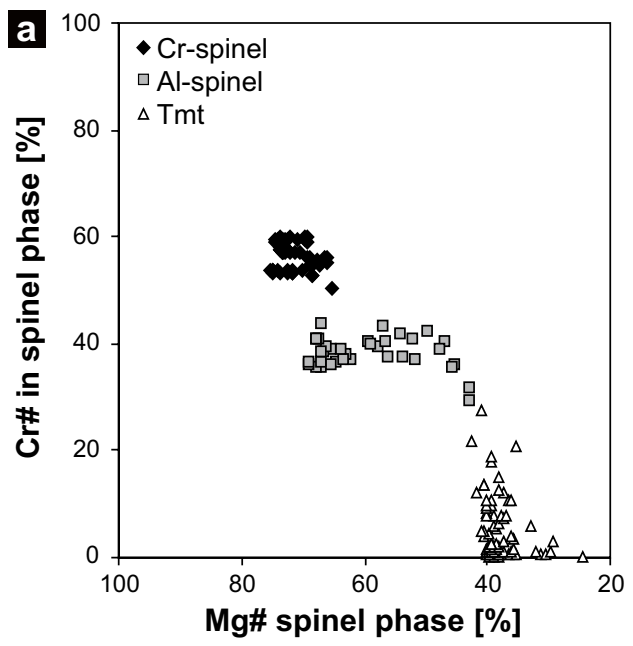

\section{Magnetic transition temperatures}

Temperature-dependent magnetic susceptibility $\kappa(T)$-curves of the tephra samples are mostly complex and show up to three magnetic transition temperatures in the heating curve if measured in an argon atmosphere. The first transition temperature $\left(T_{\mathrm{C}} 1\right)$ varies between 172 and $264{ }^{\circ} \mathrm{C}$ and also occurs in the cooling curve (Table 2). This transition temperature is the $T_{\mathrm{C}}$ of the homogeneous $\mathrm{Mg}-\mathrm{Al}$-rich titanomagnetite and is in rather good agreement with the calculated $T_{\mathrm{C}}$ values given above. However, some samples show higher measured $T_{\mathrm{C}}$ than calculated $T_{\mathrm{C}}$ (maximum calculated $T_{\mathrm{C}}$ of $228^{\circ} \mathrm{C}$ ). It is also conspicuous that this $T_{\mathrm{C}} 1$ is shifted either to higher $\left(\Delta T_{\mathrm{C}} 1:-12\right.$ to $\left.-57^{\circ} \mathrm{C}\right)$ or lower $\left(\Delta T_{\mathrm{C}} 1: 15-59^{\circ} \mathrm{C}\right)$ values in the cooling curve $\left(\Delta T_{\mathrm{C}}\right.$ equals $T_{\mathrm{C}}$ from heating curve minus $T_{\mathrm{C}}$ from cooling curve). This phenomenon indicates cation ordering effects as suggested by Bowles et al. (2018, 2019), Jackson and Bowles (2014), and Harrison and Putnis (1999).

While a second transition temperature ( $T 2$ between 362 and $480{ }^{\circ} \mathrm{C}$ ) is often not reversible (e.g., Fig. 6b, d) or becomes more faint in the cooling curve, the third transition temperature $\left(T_{\mathrm{C}} 3\right.$ between 498 and $\left.566{ }^{\circ} \mathrm{C}\right)$ is mostly stable and is, therefore, interpreted as a relatively stoichiometric titanomagnetite with a composition close to the end-member magnetite. These higher transition temperatures indicate that the optically homogeneous $\mathrm{Mg}-\mathrm{Al}$-rich titanomagnetite is substantially altered.

In general, three different ferrimagnetic oxide assemblages were distinguished from the $\kappa(T)$-curves (Table 2):

- Type I curves show lower $T_{\mathrm{C}} 1$ in the heating than in the cooling curve ( $\min .170{ }^{\circ} \mathrm{C}$ ) for the homogeneous titanomagnetite (Fig. 5b, c).

- Type II shows higher $T_{\mathrm{C}} 1\left(\max .260^{\circ} \mathrm{C}\right)$ in the heating than in the cooling curve (Fig. 6b, d). This type is similar to the one reported in Jackson and Bowles (2014), where cation ordering effects through slow cooling are shifting the $T_{\mathrm{C}}$ in the heating leg to higher values.

- Type III is very different and characterized by a significant amount of maghemitization, indicated by strong differences in heating and cooling $T_{\mathrm{C}}$ (Fig. 6c), although the basanitic tephra does not show significant signs of alteration and the titanomagnetite grains themselves only show very few shrinkage cracks and the above-mentioned mottled texture in BSE images (Fig. 3b). However, in type III, $T_{\mathrm{C}} 1$ is completely overprinted by maghemitization in the heating leg. Through heating in argon atmosphere, $T_{\mathrm{C}} 1$ becomes visible in the cooling leg as in type I and II. We suggest that maghemite is reduced to titanomagnetite during heating in argon atmosphere. Therefore, we assume that titanomagnetite is not only prone to cation reordering phenomena during explosive volcanism but also to subtle magma-water interaction causing low-temperature alteration.

From these observations, we conclude that all three types are characterized by a similar $T_{\mathrm{C}} 1$ in the cooling curves ranging between 190 and $235^{\circ} \mathrm{C}$, which corresponds reasonably well with the calculated $T_{\mathrm{C}}$ from the electron microprobe analysis (114-228 ${ }^{\circ} \mathrm{C}$ ), considering $\mathrm{Mg}, \mathrm{Al}, \mathrm{Mn}$, and $\mathrm{Cr}$ in addition to $\mathrm{Ti}$ (see Table 1 ). However, $T_{\mathrm{C}} 1$ from the heating curve differs from the ones of the cooling curves in type I and II. While in type $\mathrm{I}$, the $T_{\mathrm{C}} 1$ from the heating curve is always lower than the one from the cooling curve (Fig. 5), type II shows the opposite behaviour with higher $T_{\mathrm{C}} 1$ in the heating curve (Fig. 6, Table 2).

\section{Stability tests of maghemitized titanomagnetite}

To further understand the irreversible behaviour of type III during the $\kappa(T)$-measurements, samples were additionally 
Table 2 Transition temperatures determined from $\kappa(T)$-curves in ${ }^{\circ} \mathrm{C}$

\begin{tabular}{|c|c|c|c|c|c|c|c|c|c|}
\hline \multirow[t]{2}{*}{ Sample } & \multirow[t]{2}{*}{ Depth (m) } & \multicolumn{3}{|c|}{$T_{\mathrm{C}}$ in heating curve } & \multicolumn{3}{|c|}{$T_{\mathrm{C}}$ in cooling curve } & \multirow[t]{2}{*}{$\Delta T_{\mathrm{C}} 1$} & \multirow[t]{2}{*}{ Type } \\
\hline & & $T_{\mathrm{C}} 1$ & $T 2$ & $T_{\mathrm{C}} 3$ & $T_{\mathrm{C}} 1$ & $T 2$ & $T_{\mathrm{C}} 3$ & & \\
\hline \multicolumn{10}{|c|}{ Measured in argon atmosphere } \\
\hline Мy3-050 & 0.50 & 183 & 393 & 523 & 195 & & 493 & -12 & I \\
\hline Мy3-095 & 0.95 & 179 & 462 & 548 & 209 & & 514 & -30 & I \\
\hline Мy3-150 & 1.50 & 176 & 455 & 550 & 223 & & 512 & -47 & I \\
\hline Мy3-185 & 1.85 & 178 & 470 & & 229 & & 520 & -51 & I \\
\hline Мy3-250 & 2.50 & 172 & 464 & & 217 & & 513 & -45 & I \\
\hline Мy3-320 & 3.20 & 174 & 474 & & 230 & 458 & & -56 & I \\
\hline Му3-360 & 3.60 & 176 & 464 & & 228 & 445 & & -52 & I \\
\hline Мy3-420 & 4.20 & 173 & 437 & 548 & 200 & 438 & & -27 & I \\
\hline Мy3-455 & 4.55 & & & & & & & & $\mathrm{pm}$ \\
\hline Мy3-530 & 5.30 & & & & & & 517 & & $\mathrm{pm}$ \\
\hline My6-025 & 0.25 & 250 & 496 & 558 & 191 & & 561 & 59 & II \\
\hline My6-090 & 0.90 & & 491 & 547 & 234 & 455 & 531 & & III \\
\hline My6-200 & 2.00 & & 419 & 550 & 221 & 412 & 539 & & III \\
\hline My6-245 & 2.45 & & 480 & 553 & 224 & 396 & 532 & & III \\
\hline My6-300 & 3.00 & & 457 & 559 & 217 & 418 & 544 & & III \\
\hline My6-305 & 3.05 & & 477 & 548 & 212 & & 521 & & III \\
\hline My6-325 & 3.25 & & 475 & 551 & 226 & 454 & 541 & & III \\
\hline My6-380 & 3.80 & & 476 & 549 & 236 & 420 & 498 & & III \\
\hline My6-420 & 4.20 & & 468 & 557 & 234 & & 514 & & III \\
\hline Мy6-485 & 4.85 & & 458 & 538 & 215 & & 547 & & III \\
\hline Мy6-560 & 5.60 & 264 & 456 & 535 & 225 & 425 & 531 & 39 & II \\
\hline Мy6-615 & 6.15 & 223 & 488 & 566 & 208 & & 551 & 15 & II \\
\hline My6-680 & 6.80 & 199 & 440 & 522 & 221 & 432 & 531 & -22 & I \\
\hline My6-690 & 6.90 & 177 & 467 & 557 & 225 & 442 & 536 & -48 & I \\
\hline My6-725 & 7.25 & 173 & 478 & 558 & 217 & & 524 & -44 & I \\
\hline My6-745 & 7.45 & 176 & 467 & 562 & 232 & 477 & 541 & -56 & I \\
\hline My6-790 & 7.90 & & 451 & & & & & & $\mathrm{pm}$ \\
\hline My6-840 & 8.40 & & 362 & 498 & & 490 & & & $\mathrm{pm}$ \\
\hline Bo1a & - & & 424 & 573 & 200 & & 577 & & III \\
\hline Bo3d & - & & 432 & 559 & 215 & & 555 & & III \\
\hline \multicolumn{10}{|c|}{ Measured in ambient atmosphere (air) } \\
\hline My6-300bx & 3.00 & & 454 & 557 & & 440 & & & III \\
\hline My6-680bx & 6.80 & 197 & 441 & & & 432 & & & $\mathrm{I} \rightarrow \mathrm{III}$ \\
\hline My6-745bx & 7.45 & 174 & 421 & 578 & & 425 & 507 & & $\mathrm{I} \rightarrow \mathrm{III}$ \\
\hline My6-745b2x & 7.45 & & 425 & 541 & & 406 & 516 & & III \\
\hline Bolbx & - & & 420 & & & 455 & & & III \\
\hline
\end{tabular}

Bold values refer to dominant phases in the $\kappa(T)$-curves. Examples of different types of observed curves can be seen in Fig. 6. Samples of footwall tuff with dominant paramagnetic behaviour are also listed (pm) measured in ambient atmosphere to evaluate the influence of the surrounding gas phase during heat treatment on the ferrimagnetic oxides. Figure 7a shows a measurement in ambient atmosphere compared to one in argon atmosphere. During heating up to $700{ }^{\circ} \mathrm{C}$, the $\kappa(T)$-curves of both measurements are nearly identical, but the cooling curves are significantly different. The sample measured in argon atmosphere shows a significantly lower $T_{\mathrm{C}}$ with a peak around $200{ }^{\circ} \mathrm{C}\left(T_{\mathrm{C}} 1\right)$. Samples measured in ambient atmosphere do not show this lower $T_{\mathrm{C}} 1$ peak in the cooling curve; instead, they show a similar transition temperature (between 400 and $440{ }^{\circ} \mathrm{C}$ ) in the heating and cooling curve and the overall susceptibility at room temperature is lower. The $\kappa(T)$-curves clearly suggest two different mineral reactions during heating in the different gas environments. In argon atmosphere, the titanomaghemite is transformed into Ti-rich titanomagnetite with a $T_{\mathrm{C}}$ near $200{ }^{\circ} \mathrm{C}$, while in ambient atmosphere, the titanomaghemite is transformed into Ti-poor titanomagnetite 
a



600
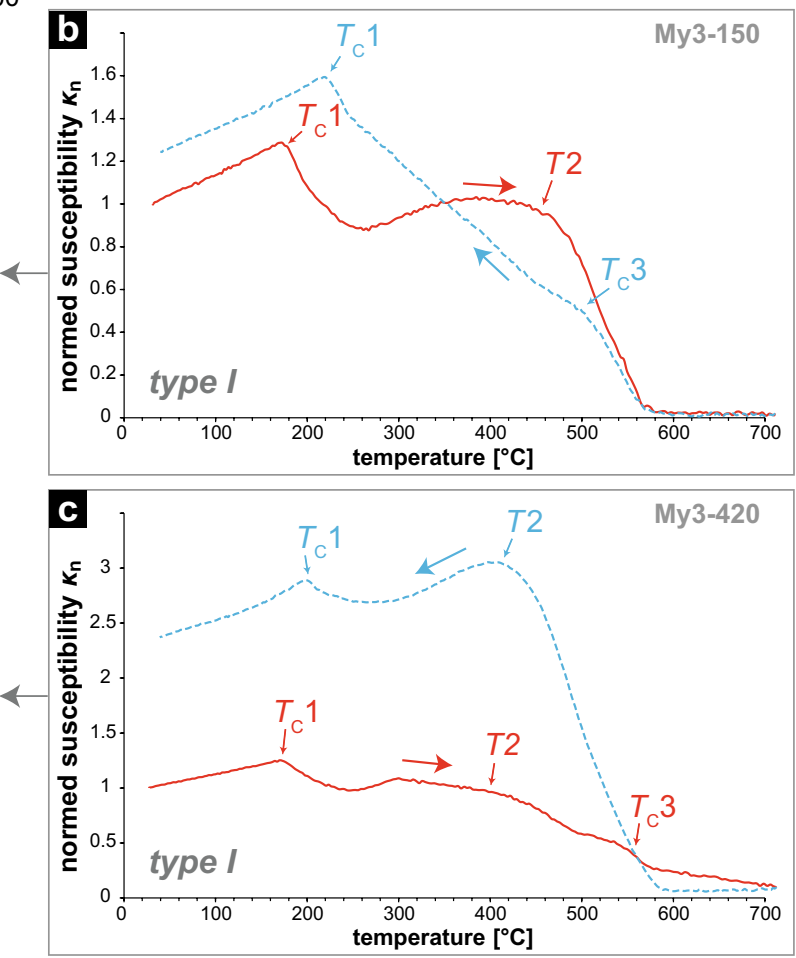

Fig. 5 a Transition temperatures of samples from drill core My-3 in dependence of depth. Filled symbols represent the dominant phase; open symbols describe transition temperatures of the less dominant peak in $\kappa(T)$-curves. Compared to My-6 (Fig. 6), only type I behav-

iour is present. b, c Examples of typical $\kappa(T)$-curves. $\kappa_{\mathrm{n}}$ is normalized to $\kappa$ at room temperature. Heating curves are plotted in red and dashed cooling curves in blue

with a $T_{\mathrm{C}}$ between 400 and $440{ }^{\circ} \mathrm{C}$, and the distinctly lower intensity of magnetic susceptibility in the cooling curve suggests the formation of a paramagnetic phase like ilmenite.

Therefore, the second phase in our $\kappa(T)$-curves can be interpreted as an unstable titanomaghemite with a transition temperature between 350 and $550^{\circ} \mathrm{C}$. A similar behaviour has been observed previously for titanomaghemite in hydrothermally altered basalts from the Krafla caldera, where low-temperature oxidation $\left(<350^{\circ} \mathrm{C}\right)$ produced titanomaghemite, which shows a transition temperature of $495^{\circ} \mathrm{C}$ (Oliva-Urcia et al. 2011).

To better understand the transformation of titanomaghemite, we made multiple stepwise heating cycles in argon atmosphere (Fig. 7b). While having completely reversible $\kappa(T)$-curves up to $T_{\max }=325^{\circ} \mathrm{C}$, a beginning transformation of titanomaghemite can be observed by a decrease in susceptibility during a $15 \mathrm{~min}$ hold at $T_{\max }=425^{\circ} \mathrm{C}$. This transformation is completed during heating up to $T_{\max }=530{ }^{\circ} \mathrm{C}$ and the $T_{\mathrm{C}} 1$ of titanomagnetite is now observed in the cooling curve.

All investigated samples from this study show signs of maghemitization (Figs. 5, 6 and Table 2), but type III from the central part of the tephra layer in drill core My-6 (Fig. 6a) represents samples, where no $T_{\mathrm{C}} 1$ has been originally observed in the initial heating curve. Therefore, we

assume that in these samples, the whole grain volume of titanomagnetite is affected by maghemitization, while in the other types, the maghemitization is not pervasive. This finding is surprising when compared to the BSE images of untreated samples, where no significant sign of maghemitization is visible. Only very few shrinkage cracks and, with high SEM contrast settings, a faint mottled substructure at outer rims of the titanomagnetite can be seen (Fig. 3b). To our knowledge, most other studies of maghemitized titanomagnetite show much more distinct substructures in the ferrimagnetic grains (e.g., Akimoto et al. 1984; Dunlop and Özdemir 1997; Oliva-Urcia et al. 2011).

To verify if these substructures are related to the maghemitization, embedded and polished thin sections of samples heated in argon and ambient atmosphere of up to $700{ }^{\circ} \mathrm{C}$ were also investigated by BSE imaging (Fig. 8a, b). Titanomagnetite measured in ambient atmosphere shows oxyexsolutions of very fine ilmenite needles (Fig. 8b) distributed in a similar pattern as the faint mottled substructure of the untreated sample (Fig. 3b). This observation confirms that titanomaghemite transforms into oxyexsolved titanomagnetite and ilmenite. The faint mottled substructures, as a first sign of maghemitization in the crystal lattice, act as weak spots for further oxidation 
a transition temperatures $\left[{ }^{\circ} \mathrm{C}\right]$

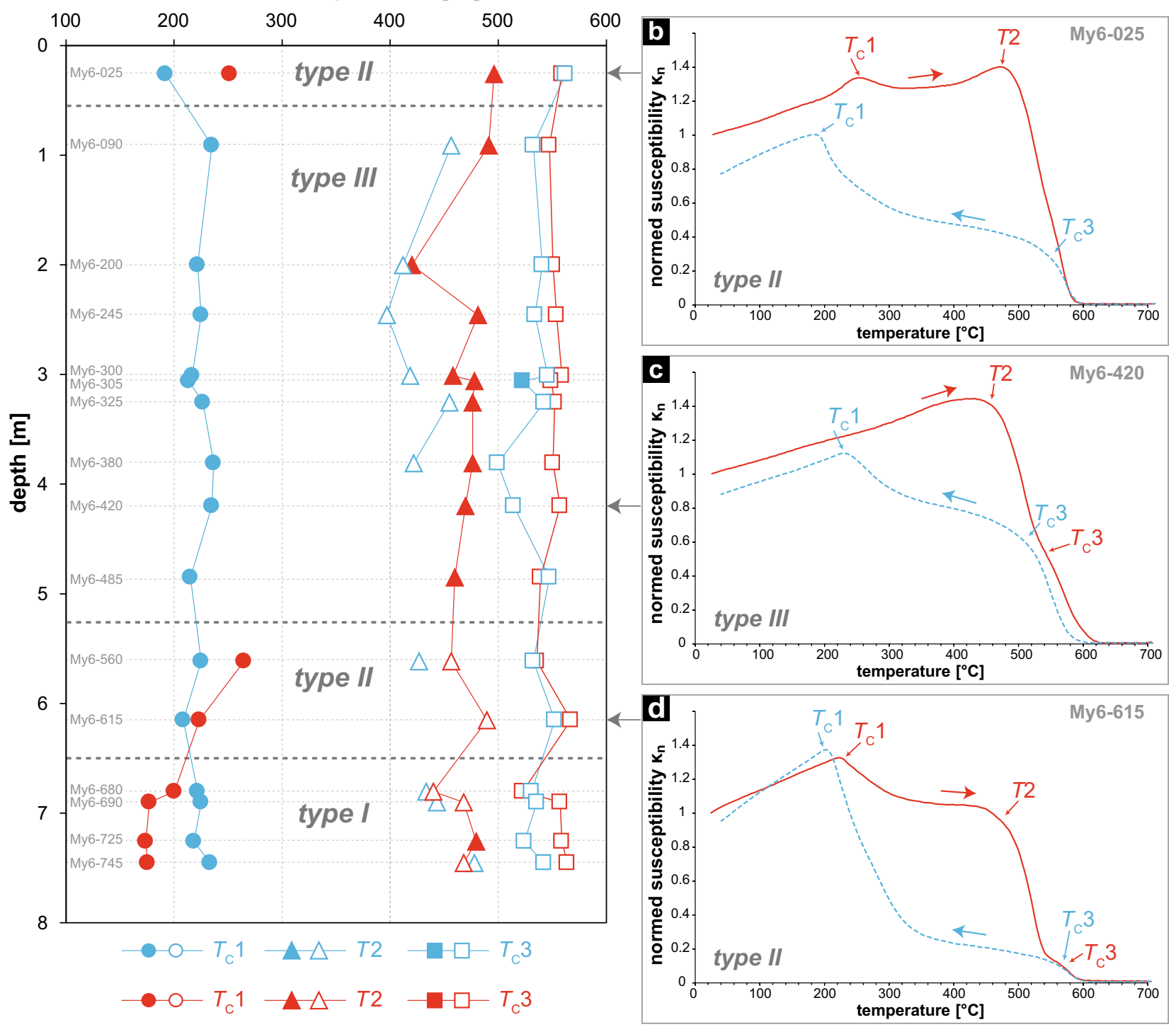

Fig. 6 a Transition temperatures of samples from drill core My-6 in dependence of depth. Filled symbols represent the dominant phase; open symbols describe transition temperatures of the less dominant peak in $\kappa(T)$-curves. Through the differences of $T_{\mathrm{C}} 1$ from the heating (red) and cooling curve (blue) or the complete absence of $T_{\mathrm{C}} 1$ in the

processes like the high-temperature oxyexsolution of ilmenite (e.g., Akimoto et al. 1984; Dunlop and Özdemir 1997).

In contrast, titanomaghemite, which was heated in argon atmosphere, does not show any mottled substructures after the heat treatment (Fig. 8a). This behaviour explains the observation in $\kappa(T)$-curves, where the susceptibility signal of maghemite is suppressed or completely vanishes in the cooling curve (Fig. 7a), confirming the formation of homogeneous titanomagnetite. heating curve; three different types (I, II, III) were distinguished. b-d Examples of typical $\kappa(T)$-curves are shown on the right side for type II and III. $\kappa_{\mathrm{n}}$ normalized to $\kappa$ at room temperature. Heating curves are plotted in red; dashed cooling curves in blue

\section{Discussion}

As shown by our results, tephra deposits from the Mýtina Maar contain $\mathrm{Cr}-\mathrm{Al}$-spinel cores, mantled by a more Al-rich spinel and rimmed by $\mathrm{Mg}-\mathrm{Al}$-rich titanomagnetite which is suggested to originate from a fractionated alkaline $\mathrm{CO}_{2}$-rich mantle melt (e.g., Jones and Wyllie 1985). Mineral chemical investigations of titanomagnetite yielded a large concentration of the cations $\mathrm{Cr}, \mathrm{Al}, \mathrm{Mg}$, and $\mathrm{Mn}$ with $0.81 \mathrm{cpfu}$, and of Ti with $0.29 \mathrm{cpfu}$. The calculated $T_{\mathrm{C}}$ of such a Mg-Alrich titanomagnetite (Engelmann 2008) is around $208{ }^{\circ} \mathrm{C}$ 




Fig. 7 a $\kappa(T)$-measurements of sample Bo1 in Ar (blue, Bola) and ambient atmosphere (red, Bolbx) show significant differences in the cooling curves (dashed lines). Only the Ar-curve is showing $T_{\mathrm{C}} 1$ during cooling. b Multicycle runs in Ar with one and the same sample (Bo3a) and stepwise increasing of $T_{\max }$ from 325 to $630^{\circ} \mathrm{C}$. $T_{\max }$ was maintained for $15 \mathrm{~min}$, respectively, followed by cooling to room



temperature (dashed line) and subsequent low-temperature measurement. Then, the next high-temperature measurement was performed with $T_{\max }$ increased by $100{ }^{\circ} \mathrm{C}$. During constant $T_{\max }$ at $425{ }^{\circ} \mathrm{C}$ for $15 \mathrm{~min}$, a drop in $\kappa$ reveals the transition of titanomaghemite. During heating to $530{ }^{\circ} \mathrm{C}$, the transition is completed and $T_{\mathrm{C}} 1$ appears in the cooling curve



Fig. 8 BSE images of titanomagnetite- and Al-spinel rims around $\mathrm{Cr}$-spinel after $\kappa(T)$-measurement of the sample Bo1 with a heating in Argon atmosphere (Bo1a), showing no mottled substructure in titanomagnetite, and $\mathbf{b}$ heating in ambient atmosphere (Bo1bx) during $\kappa(T)$-measurement, with very fine needle-like substructures accu-

(average). While electron microprobe investigations did not show any significant variation in the chemical composition of $\mathrm{Mg}$-Al-rich titanomagnetite compared to the other spinel phases (Table 1), temperature-dependent magnetic susceptibility measurements in an argon atmosphere revealed a complex behaviour with up to three magnetic transition temperatures and irreversible heating-cooling curves. We interpret this behaviour to reflect different degrees of subtle



mulated along lines in titanomagnetite. Compare to Fig. 3 where the mottled substructure of the initial titanomagnetite is shown. The features from $\mathbf{a}$ and $\mathbf{b}$ are representatives for the whole sample investigated, respectively

maghemitization in the $\mathrm{Mg}-\mathrm{Al}$-rich titanomagnetite grains. Nevertheless, many of our investigated samples show the $T_{\mathrm{C}}$ of the homogeneous $\mathrm{Mg}-\mathrm{Al}$-rich titanomagnetite in the cooling curves, but the $T_{\mathrm{C}}$ from the heating curves show either distinctly lower or higher $T_{\mathrm{C}} \mathrm{s}$ than the one calculated from the mineral chemical composition. $T_{\mathrm{C}}$ retrieved from the cooling curve is close to the calculated $T_{\mathrm{C}}$ (e.g., see sample My6-615 in Fig. 6d and Table 2), an observation in 
agreement with earlier reports by Jackson and Bowles (2014 and references therein). If $T_{\mathrm{C}} 1$ from the heating and cooling curve are compared per sample, a $\Delta T_{\mathrm{C}} 1$ between -56 and $+59{ }^{\circ} \mathrm{C}$ is observed (Table 2, Fig. 9). This deviation, which becomes visible during $\kappa(T)$-measurements (up to $700{ }^{\circ} \mathrm{C}$ ) in an argon atmosphere, suggests variations in the degree of cation ordering processes as already suggested by Jackson and Bowles (2014) for pyroclastic deposits from the Mt. St. Helens and Novarupta volcanoes, and implicates a possible relationship either with emplacement temperature or cooling rate of pyroclastic deposits. This will be discussed in the following.

\section{Chemical composition and Curie temperature in Mg-Al-rich titanomagnetite: a tool to discriminate cation ordering?}

Differences between Curie temperatures obtained from $\kappa(T)$ heating and cooling curves $\left(\Delta T_{\mathrm{C}}\right)$ are reported for pyroclastic deposits by Bowles et al. (2013) and Jackson and Bowles (2014), but also for synthetic titanomagnetites in equilibrium with ilmenite, which were drop-quenched within a minute from 1100 to $1300{ }^{\circ} \mathrm{C}$ down to room temperature (Lattard et al. 2006). Short-term thermomagnetic runs, in our case heating up to $700{ }^{\circ} \mathrm{C}$ with heating rates of ca. $11^{\circ} \mathrm{C} / \mathrm{min}$, reduce or eliminate the irreversibility of $T_{\mathrm{C}}$. The observed changes in $T_{\mathrm{C}}$ during $\kappa(T)$-measurements are in all these studies related to homogeneous titanomagnetite, albeit the chemical compositions are different. Samples from Mt. St. Helens contain a significantly lower concentration of $\mathrm{Al}$ and $\mathrm{Mg}$ with $0.19 \mathrm{cpfu}$ and Novarupta with $0.17 \mathrm{cpfu}$ (Bowles et al. 2013; Jackson and Bowles 2014) than the Mg-Al-rich titanomagnetite from the Mýtina Maar with $0.81 \mathrm{cpfu}(\mathrm{Al}$, $\mathrm{Mg}, \mathrm{Mn}$, and $\mathrm{Cr}$ ). Titanomagnetite from the synthetic study of Lattard et al. (2006) does only contain $\mathrm{Fe}^{2+}, \mathrm{Fe}^{3+}$, and $\mathrm{Ti}^{4+}$. The experimental study (Lattard et al. 2006) as well as the one on natural titanomagnetite by Bowles et al. (2013) and Jackson and Bowles (2014) relate this phenomenon to cation disordering/reordering phenomena. $T_{\mathrm{C}}$ from the cooling curve is described to be independent from thermal history and, therefore, is interpreted to reflect more reliably the titanomagnetite composition (Jackson and Bowles 2018).

A generalized structural formula, which considers the cation ordering, can be written as $\mathrm{Fe}^{3+}{ }_{b} \mathrm{Fe}^{2+}{ }_{1-b}\left(\mathrm{Fe}^{2+}{ }_{b+x} \mathrm{Fe}^{3+}{ }_{2-2 x-b} \mathrm{Ti}^{4+}{ }_{x}\right) \mathrm{O}_{4}$, where $0 \leq x \leq 0.5$, and the inversion parameter $b$ ranges from 0 (normal spinel with no tetrahedral $\mathrm{Fe}^{3+}$ ) to 1 (inverse spinel with only $\mathrm{Fe}^{3+}$ in tetrahedral sites; see Bowles et al. 2013 and references therein). Bowles et al. (2013) have calculated $T_{\mathrm{C}} \mathrm{s}$ from $408{ }^{\circ} \mathrm{C}$ for the most ordered arrangement $(b=1)$ to $343{ }^{\circ} \mathrm{C}$ for random cation arrangement $(b=2 / 3)$ for an ulvöspinel component $X_{\text {usp }}=0.3$ using the Weiss molecular field theory model of Stephenson (1972). Measured $T_{\mathrm{C}} \mathrm{s}$ from the cooling curve are constant at about $370{ }^{\circ} \mathrm{C}$ and indicate a lessordered cation distribution state than those retrieved from the heating curves ranging between about 370 and $500{ }^{\circ} \mathrm{C}$ (see Fig. 6 in Jackson and Bowles 2014). Bowles et al. (2013) explained the discrepancy between calculated and measured $T_{\mathrm{C}}$ by arguing that $\mathrm{Mg}^{2+}$ and $\mathrm{Al}^{3+}$ cation substitution is more sensitive on the cation reordering process than only $\mathrm{Ti}^{4+}$ cation substitution, since a higher concentration of these cations allows a higher disordering state.



Fig. 9 Difference between Curie temperature from $\kappa(T)$ heating and cooling curve $\left(\Delta T_{\mathrm{C}}\right)$ as a function of Curie temperature $\left(T_{\mathrm{C}}\right)$ from the $\mathbf{a}$ heating and $\mathbf{b}$ cooling run. Top and bottom samples of drill cores My-3 and My- 6 are marked. Dashed red and blue lines indicate missing samples in between, where $T_{\mathrm{C}} 1$ is masked by maghemitization and $\Delta T_{\mathrm{C}}$ cannot be inferred (Fig. 6). Type I and II indicate type of

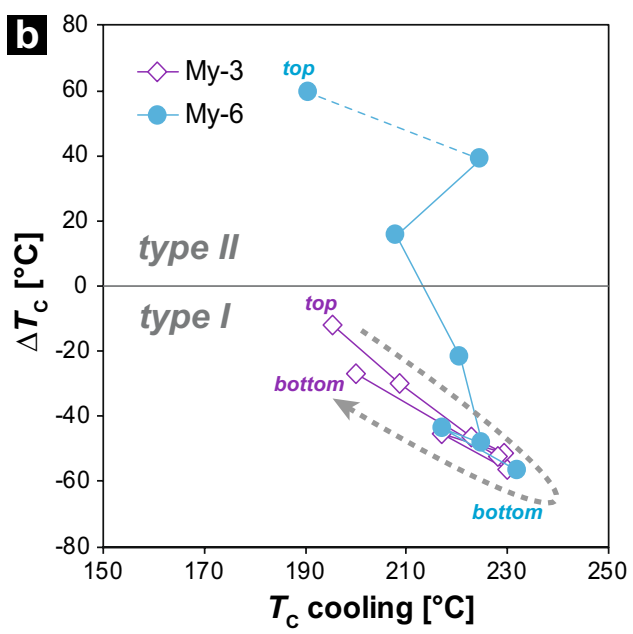

$\kappa(T)$-curve (Table 2). Grey circle in a highest quenched-in disorder is suggested to indicate a fast cooling rate. The grey arrow in $\mathbf{b}$ this trend is interpreted to indicate a fractionation trend of magma in the magma chamber or a changing crystallization temperature (see text for further explanation) 
While $\mathrm{Ti}^{4+}$ cations only occupy octahedral sites, $\mathrm{Mg}$ and $\mathrm{Al}$ cations are assumed to partition between tetrahedral and octahedral sites.

What we learn up to now from these studies is that we can obtain information on the relative cation ordering/disordering from $\kappa(T)$-measurements. All studies which we refer to obtained $T_{\mathrm{C}}$ from $\kappa(T)$-measurements with heating/cooling rates of ca. $10^{\circ} \mathrm{C} / \mathrm{min}$ in an AGICO Kappabridge. In case of the Mt. St. Helens and Novarupta samples, a more disordered state is retrieved from the cooling curve (positive $\Delta T_{\mathrm{C}}$ ), suggesting that the emplacement temperatures were hot enough to enable cation ordering processes after deposition. According to this, the cooling rate during natural emplacement was lower than during measurement in the Kappabridge.

Few of our samples with type II behaviour (Table 2, Fig. 9) are similar to those described for pyroclastic density current deposits from Mt. St. Helens and Novarupta (Jackson and Bowles 2014) with positive $\Delta T_{\mathrm{C}}$. A major difference to our results is the maximum observed $\Delta T_{\mathrm{C}}$, which is $\sim 150{ }^{\circ} \mathrm{C}$ in the case studies from Mt. St. Helens and Novarupta (Jackson and Bowles 2014) compared to a maximum $\Delta T_{\mathrm{C}} 1$ of $\sim 59^{\circ} \mathrm{C}$ in our example from the Mýtina Maar (Fig. 9). The comparison between our composition and the one reported in Jackson and Bowles (2014) implies that the relationship between cation ordering-disordering and the cooling rate is quite complex, which is understandable in the light of the different cation occupation models for the tetrahedral and octahedral sites. The effect of cation substitution in titanomagnetite on $\Delta T_{\mathrm{C}}$ is not well constrained yet for $\mathrm{Mg}-\mathrm{Al}$-rich titanomagnetite and needs the further experimental investigations.

Nevertheless, a positive $\Delta T_{\mathrm{C}}$ (as for type II samples) suggests that the cooling rate during the $\kappa(T)$-measurements is higher than during natural pyroclastic deposit emplacement. Most of our samples, however, show a vice versa behaviour with a shift towards higher $T_{\mathrm{C}} \mathrm{S}$ in the cooling curve compared to the heating curve (type I, negative $\Delta T_{\mathrm{C}}$ in Table 2 and Fig. 9a, b). Our type I behaviour is comparable to the observations of Lattard et al. (2006) for intermediate titanomagnetite-ilmenite assemblages synthesized at $1300{ }^{\circ} \mathrm{C}$, which were drop-quenched within a minute to room temperature. The lower $T_{\mathrm{C}} \mathrm{s}$ from the heating curves, therefore, indicate a higher degree of disorder in the initial sample than after heating up with a heating/cooling rate of $11^{\circ} \mathrm{C} / \mathrm{min}$ in the Kappabridge. Figure $9 \mathrm{a}$ shows $\Delta T_{\mathrm{C}}$ versus $T_{\mathrm{C}}$ from the heating curve. The largest negative $\Delta T_{\mathrm{C}}$ values (between -40 and $-60{ }^{\circ} \mathrm{C}$ ) are found in samples with the lowest $T_{\mathrm{C}}$ in the heating curve, which is suggested to reflect samples with the highest quenched-in cation disorder in the $\mathrm{Mg}-\mathrm{Al}-$ rich titanomagnetite. These type I samples with the largest negative $\Delta T_{\mathrm{C}}$ (grey circle in Fig. 9a) supposedly experienced the fastest cooling rates.
The Mg-Al-rich titanomagnetite from the Mýtina Maar shows $T_{\mathrm{C}} \mathrm{s}$ from cooling runs ranging between 191 and $232{ }^{\circ} \mathrm{C}$ for type I and II (Fig. 9b and Table 2), which is in good agreement with the calculated average $T_{\mathrm{C}}\left(208 \pm 14{ }^{\circ} \mathrm{C}\right)$ from the chemical composition (Table 1). We relate the slight differences to the original homogeneous $\mathrm{Mg}$-Al-rich titanomagnetite composition. Especially in samples from drill core My-3, we observed a slight decrease in $T_{\mathrm{C}}$ cooling from bottom to mid layers, followed by an increase from mid layers to top (grey arrow in Fig. 9b) and some variation can be seen in core My- 6 as well, although only a decreasing trend. This can be either interpreted in terms of tiny changes in magma composition (changes in $\mathrm{Fe} /$ substituted cation ratio and fractionation trend), or a changing crystallization temperature or cooling rate. Regarding the latter, rapid growing of titanomagnetite crystals can lead to compositional variations due to incorporation of $\mathrm{Al}$ and $\mathrm{Mg}$ at the expenses of $\mathrm{Ti}$, as shown for titanomagnetite from alkaline rocks of Mt. Etna (Mollo et al. 2013).

Both of the studies on natural titanomagnetite from pyroclastic deposits (Jackson and Bowles 2014 and this study) contain, in addition to optically homogenous titanomagnetite, a second, higher $T_{\mathrm{C}}$. In case of the Mt. St. Helens and Novarupta samples, the higher $T_{\mathrm{C}}$ at about $550{ }^{\circ} \mathrm{C}$ is related to oxyexsolved magnetite-ilmenite grains (Bowles et al. 2013). Their abundance is higher in samples with estimated emplacement temperatures $<600{ }^{\circ} \mathrm{C}$ (Jackson and Bowles 2014) and the higher $T_{\mathrm{C}}$ remains unaffected during $\kappa(T)$-measurements. This is clearly different to the Mýtina Maar samples where transition temperatures above $400{ }^{\circ} \mathrm{C}$ (especially for type III samples) are related to titanomaghemite, which are characterized by an irreversible behaviour during heating. Our results show that titanomaghemite either transforms into Ti-poor titanomagnetite and ilmenite (in ambient atmosphere) or into titanomagnetite (in argon atmosphere) during heating at about $425{ }^{\circ} \mathrm{C}$ (Figs. 7, 8). The occurrence of type III $\kappa(T)$-curves (Fig. $6 \mathrm{c}$ ) indicates a significant amount of maghemitization of titanomagnetite in the affected samples with complete masking of the effects of cation ordering. This observed maghemitization suggests that emplacement temperatures were significantly lower in the Mýtina Maar deposits compared to Mt. St. Helens and Novarupta deposits.

\section{Implications of emplacement mechanisms from $\Delta T_{C}$}

In our study, three different types of $\kappa(T)$-behaviour have been distinguished for all measured samples around the Mýtina Maar, with $\kappa(T)$-curves of type I (indicating a faster cooling rate than the $11^{\circ} \mathrm{C} / \mathrm{min}$ in KLY-4S Kappabridge), type II (slower cooling rate than the Kappabridge), and type III (effect of cation ordering masked by maghemitization). 
In the deposits of the southern drill core My-3, we can observe only type I behaviour (Fig. 5), indicating that the titanomagnetites in this ca. $4 \mathrm{~m}$-thick tephra layer suffered rapid cooling rates. We hypothesize that the tephra from drill core My-3 was ejected from the Mýtina maar-diatreme volcano and slowly piled up with low emplacement temperature. Because of the explosive magma-water interaction of maar-diatreme volcanoes, a large amount of thermal energy can be dissipated and partially converted into kinetic energy during phreatomagmatic eruptions. Cooling in air through fast uplifting in the eruption column with subsequent slow fallout deposition can be an additional factor (Thomas and Sparks 1992). Low emplacement temperatures $\left(180-270{ }^{\circ} \mathrm{C}\right)$ and a low amount of the total thermal energy from the magma preserved at time of deposition (12-23\%) is a characteristic feature of mafic monogenetic volcanic structures (e.g., van Otterloo and Cas 2016).

In the south-western deposits of My-6, however, type I behaviour only occurs in the lowermost $\sim 1 \mathrm{~m}$ of the drill core (Fig. 6). Above, the pyroclastic deposit show type II behaviour, followed by a middle part of a $\sim 6.5 \mathrm{~m}$ deposit with type III behaviour. Note that we probably do not have preserved the top of the pyroclastic deposits due to erosion or agricultural activity. The more complex behaviour of the pyroclastics from drill core My- 6 indicates a different cooling history throughout its deposition. From the observation of $\kappa(T)$-curves, we infer rapid quenching at the bottom layers (type I), followed by a slower cooling rate (type II) in the hanging wall deposits (see $\Delta T_{\mathrm{C}} 1$ development in Figs. 6 and 9). This observation suggests a higher volume of tephra material that was ejected during a shorter period of time, compared to deposits of My-3. Within this tephra material, a significant maghemitization is observed, masking the original $T_{\mathrm{C}}$ of the homogeneous titanomagnetite over several meters (type III). Maghemitization is an oxidation process at low temperatures $\left(\leq 200{ }^{\circ} \mathrm{C}\right)$, which is not described to occur syneruptively (e.g., Dunlop and Özdemir 1997) and, therefore, occurs primarily after emplacement. To allow the oxidation process from $\mathrm{Fe}^{2+}$ to $\mathrm{Fe}^{3+}$ by exchange of electrons at low temperatures, fluids are necessary (Dunlop and Özdemir 1997). Dry and hot pyroclastic rocks (such as at Mt. St. Helens) do not show maghemitization in titanomagnetite (Bowles et al. 2013) despite the high oxygen fugacity during sub-aerial eruption and emplacement.

Changing eruption styles due to varying magma/water ratios are a characteristic feature of maar-diatreme volcanoes. Depending on the availability of water in the root zone, the eruption style can change from the initial phreatic and phreatomagmatic eruptions to phreato-Strombolian and Strombolian eruptions in the later stages and vice versa (Kienle et al. 1980; Ort et al. 2018). These differences in eruption styles are reflected in variations in deposit distribution, ejecta volumes, and deposit characteristics. In part, these variations can be attributed to different explosion depth and magma/water ratios, resulting in fallout or pyroclastic density currents. As an example, the 1977 Ukinrek maar eruption, e.g., started with phreatomagmatic explosions with significantly higher eruption columns, followed by weak phreato-Strombolian activity in between, yielding only spattered magmatic material by local magma-water interaction directly on the surface, together with steam clouds (Ort et al. 2018).

The different $\Delta T_{\mathrm{C}}$ in our study suggests different cooling histories of the tephra deposits, and a change in eruption style during the formation of the Mýtina maar from a more phreatomagmatic to a more phreato-Strombolian type could be a likely scenario (Fig. 10). We propose that a more phreato-Strombolian eruption type with less explosive magma-water interaction leads to higher emplacement temperatures with elongated heat storage, which can explain the slower cooling rate of the type II tephra deposits of My-6. The stronger maghemitization in the centre of this unit suggests the deposition of more $\mathrm{H}_{2} \mathrm{O}$-rich deposits as it is described as well, e.g., for pyroclastic density currents (e.g., Ort et al. 2018 and references therein).

Our study is a new approach to discriminate different cooling histories in pyroclastic maar deposits using the Curie temperature of titanomagnetite. We suggest that this method has the potential to discriminate different emplacement modes resulting from different eruption styles. Further studies in combination with more in-depth volcanologic investigations concerning the accretion history of the lapilli and experimental studies concerning the composition of titanomagnetites and their $\Delta T_{\mathrm{C}}$ dependence have to be done to refine the applicability of this method.

\section{Conclusions and outlook}

Our results reveal $\mathrm{Mg}-\mathrm{Al}$-rich titanomagnetites as the main ferrimagnetic oxide phases in the phreatomagmatic tephra deposits of the Pleistocene Mýtina Maar located in the western Eger Rift area. Temperature-dependent magnetic susceptibility measurements revealed a significant difference in Curie temperatures retrieved from the heating and cooling curves $\left(\Delta T_{\mathrm{C}}\right)$ of the titanomagnetite, presumably caused by changes in cation ordering during emplacement of the tephra, which is interpreted to allow a distinction of cooling rates. All samples show different degrees of maghemitization with transition temperatures above $360{ }^{\circ} \mathrm{C}$, but the homogeneous component is still observable in two out of three types of $\kappa(T)$-curves.

Negative $\Delta T_{\mathrm{C}}$ indicates that the original deposited titanomagnetite has cooled faster and, therefore, has memorized a lower degree of cation ordering compared to the heating/ cooling rate of $11{ }^{\circ} \mathrm{C} / \mathrm{min}$ used in the instrument. Therefore, 


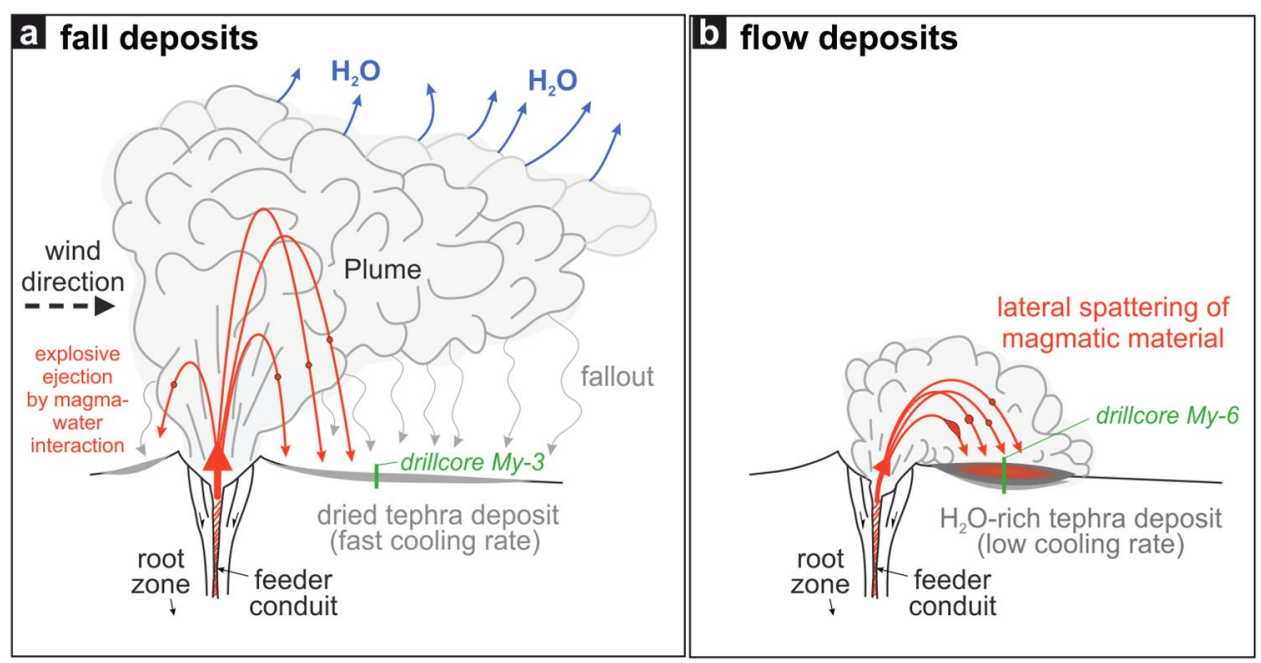

Fig. 10 Sketch with different eruption styles and deposition mechanisms (phreatomagmatic and phreato-Strombolian) and a possible scenario for the investigated Mýtina drill cores My-3 and My-6 (modified after Schumacher and Schmincke 1995; Ort et al. 2018). a The phreatomagmatic eruption includes material transport to great heights

we conclude that pyroclastic deposits from the Mýtina Maar with type I behaviour lost their thermal energy quite rapidly. Type II samples in drill-core My-6 with positive $\Delta T_{\mathrm{C}}$ indicate that the deposits sustained a certain temperature for a longer time interval than the one with type I behaviour. In the central part of this deposit, the maghemitization is the strongest and affects the whole grain volume of titanomagnetite (type III), masking the original degree of cation ordering. To allow maghemitization, the water content must have been sufficient in this thick layer.

We, therefore, assume two different emplacement mechanisms for thermomagnetic type I and II: (1) A steady and relatively slow emplacement of the southern deposits (My-3 and lower part of My-6), allowing a rapid cooling and low water content, as maghemitization is not pervasive. This scenario suggests a phreatomagmatic eruption style with intense magma-water interaction when hitting the water table of an aquifer and possibly high eruption column with separation from water during subsequent fallout deposition (Fig. 10a). (2) A fast emplacement of high volume of the south-western deposits (upper part in My-6), which maintained a higher temperature for a prolonged period of time after emplacement (in comparison to tephra of My-3). This scenario could be related to a change in eruption style towards a more phreato-Strombolian style with lower eruption column and insufficient separation of water compared to a phreatomagmatic eruption (Fig. 10b), which additionally allowed the strong maghemitization in type III samples. However, a validation of these implications by further research and more drill-core investigations (also in the tephra layers NNW from the maar centre) are and deposition as ash fallout and ejected lapilli. The spread of the plume can be strongly affected by the wind direction. b The phreatoStrombolian eruption could yield a lower eruption column with lateral spattering of magmatic material

needed to understand the history of the Mýtina Maar eruption in-depth. The here given scenario is likely only one of the several possibilities explaining the different cooling rates.

Our results clearly underline the qualitative utility of Curie temperature measurements for elucidating different cooling histories of pyroclastic deposits in volcanic maardiatreme structures, although the complexity is not yet fully understood and requires further experimental studies. With respect to the inactive but not extinct Pleistocene volcanic provinces in the European Cenozoic Rift System, valuable information regarding geological hazards by maar-diatreme eruptions could be gained. Since earlier petrological studies of the Ukinrek deposits mention the occurrence of chromian spinels with rims of titanomagnetite and microprobe analysis show high amounts of $\mathrm{Al}$ and $\mathrm{Mg}$ in these spinels (Kienle et al. 1980), a composition similar to the titanomagnetite of the Mýtina deposits with high amounts of substituted cations can be expected. A mineral magnetic comparative study on tephra deposits of the 1977 Ukinrek Maar eruption would be very interesting, as a recent, very-well-studied eruption could be compared with an ancient one. This might be important concerning the evaluation of the hazard potential of dormant volcanos in the Eger Rift as well as other volcanic areas in Central Europe.

Acknowledgements Open Access funding provided by Projekt DEAL. We thank Tobias Nickschick for his kind support and Ilona Schaepan, Oona Appelt (GFZ, Potsdam), Kristian Nikoloski (AGW at KIT), and Volker Zibat (LEM at KIT) for help in sample preparation and electron microscopy. The German Research Foundation financed deepening of the boreholes (KA 902/16). Magnetic survey observations were partly 
supported by the project CzechGeo/EPOS, Grant No. LM2015079. We appreciate the helpful comments of an anonymous reviewer, Vladislav Rapprich and Wolfram Geissler.

Open Access This article is licensed under a Creative Commons Attribution 4.0 International License, which permits use, sharing, adaptation, distribution and reproduction in any medium or format, as long as you give appropriate credit to the original author(s) and the source, provide a link to the Creative Commons licence, and indicate if changes were made. The images or other third party material in this article are included in the article's Creative Commons licence, unless indicated otherwise in a credit line to the material. If material is not included in the article's Creative Commons licence and your intended use is not permitted by statutory regulation or exceeds the permitted use, you will need to obtain permission directly from the copyright holder. To view a copy of this licence, visit http://creativecommons.org/licenses/by/4.0/.

\section{References}

Ackerman L, Medaris G, Špaček P, Ulrych J (2015) Geochemical and petrological constraints on mantle composition of the Ohře(Eger) rift, Bohemian Massif: peridotite xenoliths from the České Středohoří Volcanic complex and northern Bohemia. Int J Earth Sci 104:1957-1979. https://doi.org/10.1007/s00531-014-1054-1

Akimoto T, Kinoshita H, Furuta T (1984) Electron probe microanalysis study on processes of low-temperature oxidation of titanomagnetite. Earth Planet Sci Lett 71:263-278. https://doi. org/10.1016/0012-821X(84)90091-8

Bankwitz P, Schneider G, Kämpf H, Bankwitz E (2003) Structural characteristics of epicentral areas in Central Europe: study case Cheb Basin (Czech Republic). J Geodyn 35:5-32. https://doi. org/10.1016/S0264-3707(02)00051-0

Baxter PJ, Jenkins S, Seswandhana R et al (2017) Human survival in volcanic eruptions: thermal injuries in pyroclastic surges, their causes, prognosis and emergency management. Burns 43:10511069. https://doi.org/10.1016/J.BURNS.2017.01.025

Baxter PJ, Neri A, Todesco M (1998) Physical modelling and human survival in pyroclastic flows. Nat Hazards 17:163-176. https://doi. org/10.1023/A:1008031004183

Bowles JA, Gerzich DM, Jackson MJ (2018) Assessing new and old methods in paleomagnetic paleothermometry: a test case at Mt. St. Helens, USA. Geochem Geophys Geosyst 19:1714-1730. https:// doi.org/10.1029/2018GC007435

Bowles JA, Jackson MJ, Berquó TS et al (2013) Inferred time- and temperature-dependent cation ordering in natural titanomagnetites. Nat Commun 4:1916. https://doi.org/10.1038/ncomms2938

Bowles JA, Lappe S-CLL, Jackson MJ et al (2019) Curie temperature enhancement and cation ordering in titanomagnetites: evidence from magnetic properties, XMCD, and Mössbauer spectroscopy. Geochem Geophys Geosyst 1:1. https://doi.org/10.1029/2019G C008217

Brandl PA, Genske FS, Beier C et al (2015) Magmatic Evidence for carbonate metasomatism in the lithospheric mantle underneath the Ohře (Eger) Rift. J Petrol 56:1743-1774. https://doi.org/10.1093/ petrology/egv052

Bräuer K, Kämpf H, Niedermann S, Strauch G (2018) Monitoring of helium and carbon isotopes in the western Eger Rift area (Czech Republic): relationships with the 2014 seismic activity and indications for recent (2000-2016) magmatic unrest. Chem Geol 482:131-145. https://doi.org/10.1016/J.CHEMGEO.2018.02.017
Bräuer K, Kämpf H, Strauch G (2009) Earthquake swarms in non-volcanic regions: what fluids have to say. Geophys Res Lett 36:1-5. https://doi.org/10.1029/2009GL039615

Bräuer K, Kämpf H, Strauch G (2014) Seismically triggered anomalies in the isotope signatures of mantle-derived gases detected at degassing sites along two neighboring faults in NW Bohemia, central Europe. J Geophys Res Solid Earth 119:5613-5632. https ://doi.org/10.1002/2014JB011044

Dunlop DJ, Özdemir Ö (1997) Rock magnetism: fundamentals and frontiers. Cambridge University Press, Cambridge, First

Engelmann R (2008) Bestimmung diagnostischer magnetischer Übergangstemperaturen von synthetischen Titanomagnetiten und Ilmenit-Hämatit-Mischkristallen. Ruprecht-Karls-Universität, Heidelberg

Fischer T, Horálek J, Hrubcová P et al (2014) Intra-continental earthquake swarms in West-Bohemia and Vogtland: a review. Tectonophysics 611:1-27. https://doi.org/10.1016/j.tecto.2013.11.001

Flechsig C, Heinicke J, Mrlina J et al (2015) Integrated geophysical and geological methods to investigate the inner and outer structures of the Quaternary Mýtina maar (W-Bohemia, Czech Republic). Int J Earth Sci 1:1. https://doi.org/10.1007/s00531-014-1136-0

Geissler W, Kämpf H, Bankwitz P, Bankwitz E (2004) Das quartäre Tephra-Tuff-Vorkommen von Mytina (Südrand des westlichen Eger-Grabens/Tschechische Republik): Indikationen für Ausbruchs- und Deformationsprozesse. Z. Geol, Wiss

Geissler W, Kämpf H, Seifert W, Dulski P (2007) Petrological and seismic studies of the lithosphere in the earthquake swarm region Vogtland/NW Bohemia, central Europe. J Volcanol Geotherm Res 159:33-69. https://doi.org/10.1016/j.jvolgeores.2006.06.011

Giordano G, Zanella E, Trolese M et al (2018) Thermal interactions of the AD79 Vesuvius pyroclastic density currents and their deposits at Villa dei Papiri (Herculaneum archaeological site, Italy). Earth Planet Sci Lett 490:180-192. https://doi.org/10.1016/J. EPSL.2018.03.023

Haggerty SE (1991) Oxide mineralogy of the upper mantle. Rev Miner Geochem 25:355-416

Harrison RJ, Putnis A (1999) Determination of the mechanism of cation ordering in magnesioferrite $\left(\mathrm{MgFe}_{2} \mathrm{O}_{4}\right)$ from the time- and temperature-dependence of magnetic susceptibility. Phys Chem Miner 26:322-332. https://doi.org/10.1007/s002690050192

Jackson M, Bowles J (2018) Malleable Curie temperatures of natural titanomagnetites: occurrences, modes, and mechanisms. J Geophys Res Solid Earth 123:921-940. https://doi. org/10.1002/2017JB015193

Jackson MJ, Bowles JA (2014) Curie temperatures of titanomagnetite in ignimbrites: effects of emplacement temperatures, cooling rates, exsolution, and cation ordering. Geochem Geophys Geosyst 15:4343-4368. https://doi.org/10.1002/2014GC005527

Jones AP, Wyllie PJ (1985) Paragenetic trends of oxide minerals in carbonate-rich kimberlites, with new analyses from the Benfontein Sill, South Africa. J Petrol 26:210-222. https://doi. org/10.1093/petrology/26.1.210

Kämpf H, Bräuer K, Schumann J et al (2013) CO2 discharge in an active, non-volcanic continental rift area (Czech Republic): Characterisation $(\delta 13 \mathrm{C}, 3 \mathrm{He} / 4 \mathrm{He})$ and quantification of diffuse and vent $\mathrm{CO} 2$ emissions. Chem Geol 339:71-83. https://doi. org/10.1016/j.chemgeo.2012.08.005

Kämpf H, Broge AS, Marzban P et al (2019) Nonvolcanic carbon dioxide emission at continental rifts: the Bublak Mofette Area, Western Eger Rift, Czech Republic. Geofluids 2019:1-19. https ://doi.org/10.1155/2019/4852706

Kienle J, Kyle PR, Self S et al (1980) Ukinrek Maars, Alaska, I. April 1977 eruption sequence, petrology and tectonic setting. J Volcanol Geotherm Res 7:11-37. https://doi.org/10.1016/03770273(80)90018-9 
Lattard D, Engelmann R, Kontny A, Sauerzapf U (2006) Curie temperatures of synthetic titanomagnetites in the Fe-Ti-O system: effects of composition, crystal chemistry, and thermomagnetic methods. J Geophys Res 111:28. https://doi.org/10.1029/2006J B004591

Lattard D, Sauerzapf U, Kontny A (2012) Rapid surficial oxidation of synthetic Fe-Ti oxides at high temperature: observations and consequences for magnetic measurements. Geochem Geophys Geosyst 13:1. https://doi.org/10.1029/2012GC004152

Lorenz V, Kurszlaukis S (2007) Root zone processes in the phreatomagmatic pipe emplacement model and consequences for the evolution of maar-diatreme volcanoes. J Volcanol Geotherm Res 159:4-32. https://doi.org/10.1016/j.jvolgeores.2006.06.019

Mollo S, Putirka K, Iezzi G, Scarlato P (2013) The control of cooling rate on titanomagnetite composition: implications for a geospeedometry model applicable to alkaline rocks from Mt. Etna volcano Contrib Mineral Petrol 165:457-475. https://doi. org/10.1007/s00410-012-0817-6

Mrlina J, Kämpf H, Geissler W, Van den Bogaard P (2007) Assumed quaternary maar structure at the Czech/German border between Mytina and Neualbenreuth (western Eger rift, Central Europe): geophysical, petrochemical and geochronological indications. $Z$ geol Wiss 35:213-230

Mrlina J, Kämpf H, Kroner C et al (2009) Discovery of the first Quaternary maar in the Bohemian Massif, Central Europe, based on combined geophysical and geological surveys. J Volcanol Geotherm Res 182:97-112. https://doi.org/10.1016/j.jvolgeores .2009 .01 .027

Németh K, Kereszturi G (2015) Monogenetic volcanism: personal views and discussion. Int J Earth Sci 104:2131-2146. https:// doi.org/10.1007/s00531-015-1243-6

Nickschick T, Kämpf H, Flechsig C et al (2015) CO2 degassing in the Hartoušov mofette area, western Eger Rift, imaged by $\mathrm{CO} 2$ mapping and geoelectrical and gravity surveys. Int J Earth Sci. https://doi.org/10.1007/s00531-014-1140-4

Oliva-Urcia B, Kontny A, Vahle C, Schleicher AM (2011) Modification of the magnetic mineralogy in basalts due to fluid-rock interactions in a high-temperature geothermal system (Krafla, Iceland). Geophys J Int 186:155-174. https://doi.org/10.1111/ j.1365-246X.2011.05029.X

Ort MH, Lefebvre NS, Neal CA et al (2018) Linking the Ukinrek 1977 maar-eruption observations to the tephra deposits: new insights into maar depositional processes. J Volcanol Geotherm Res 360:36-60. https://doi.org/10.1016/J.JVOLGEORES .2018.07.005

Petrovský ED, Kapička A (2006) On determination of the Curie point from thermomagnetic curves. J Geophys Res Solid Earth 111:27. https://doi.org/10.1029/2006JB004507

Porreca M, Giordano G, Mattei M, Musacchio P (2006) Evidence of two Holocene phreatomagmatic eruptions at Stromboli volcano (Aeolian Islands) from paleomagnetic data. Geophys Res Lett 33:L21316. https://doi.org/10.1029/2006GL027575

Rapprich V, Valenta J, Brož M et al (2019) A crucial site in the argument between neptunists and plutonists: reopening of the historical adit in the Komorní hůrka (Kammerbühl) volcano after 180 years. Geoheritage 11:347-358. https://doi.org/10.1007/ s12371-018-0286-Z

Rohrmüller J, Kämpf H, Geiß E et al (2018) Reconnaissance study of an inferred Quaternary maar structure in the western part of the Bohemian Massif near Neualbenreuth, NE-Bavaria (Germany). Int J Earth Sci 107:1381-1405. https://doi.org/10.1007/s0053 1-017-1543-0
Rojik P, Fejfar O, Dašková J et al (2014) Krušné hory Piedmont basins - Cheb Basin. In: Pešek J (ed) Tertiary basins and lignite deposits of the Czech Republic, Prague, pp 141-161

Ross P-S, White JDL (2012) Quantification of vesicle characteristics in some diatreme-filling deposits, and the explosivity levels of magma-water interactions within diatremes. J Volcanol Geotherm Res 245-246:55-67. https://doi.org/10.1016/j.jvolgeores .2012 .07 .006

Sauerzapf U, Lattard D, Burchard M, Engelmann R (2008) The titanomagnetite-ilmenite equilibrium: new experimental data and thermo-oxybarometric application to the crystallization of basic to intermediate rocks. J Petrol 49:1161-1185

Schumacher R, Schmincke H-U (1995) Models for the origin of accretionary lapilli. Bull Volcanol 56:626-639. https://doi. org/10.1007/BF00301467

Seifert W, Kämpf H (1994) Ba-enrichment in phlogopite of a nephelinite from Bohemia. Eur J Mineral 6:497-502. https:// doi.org/10.1127/ejm/6/4/0497

Špičáková L, Uličný D, Koudelková G (2000) Tectonosedimentary evolution of the Cheb Basin (NW Bohemia, Czech Republic) between Late Oligocene and Pliocene: a preliminary note. Stud Geophys Geod 44:556-580. https://doi.org/10.1023/A:10218 19802569

Stephenson A (1972) Spontaneous magnetization curves and curie points of cation deficient titanomagnetites. Geophys J Int 29:91-101

Thomas RME, Sparks RSJ (1992) Cooling of tephra during fallout from eruption columns. Bull Volcanol 54:542-553. https://doi. org/10.1007/BF00569939

Trolese M, Giordano G, Cifelli F et al (2017) Forced transport of thermal energy in magmatic and phreatomagmatic large volume ignimbrites: Paleomagnetic evidence from the Colli Albani volcano, Italy. Earth Planet Sci Lett 478:179-191. https://doi. org/10.1016/J.EPSL.2017.09.004

Ulrych J, Ackerman L, Balogh K et al (2013) Plio-Pleistocene basanitic and melilititic series of the Bohemian Massif: K-Ar ages, major/trace element and $\mathrm{Sr}-\mathrm{Nd}$ isotopic data. Chem Erde 73:429-450. https://doi.org/10.1016/j.chemer.2013.02.001

Valentine GA, White JDL, Ross P-S et al (2017) Updates to concepts on phreatomagmatic maar-diatremes and their pyroclastic deposits. Front Earth Sci. https://doi.org/10.3389/feart .2017 .00068

van Otterloo J, Cas RAF (2016) Low-temperature emplacement of phreatomagmatic pyroclastic flow deposits at the monogenetic Mt Gambier Volcanic Complex, South Australia, and their relevance for understanding some deposits in diatremes. J Geol Soc Lond 173:701-710. https://doi.org/10.1144/jgs2015-122

Vavryčuk V, Adamová P (2018) Detection of stress anomaly produced by interaction of compressive fault steps in the West Bohemia Swarm Region, Czech Republic. Tectonics 37:42124225. https://doi.org/10.1029/2018TC005163

Weinlich FH, Bräuer K, Kämpf H et al (1999) An active subcontinental mantle volatile system in the western Eger rift, Central Europe: gas flux, isotopic $(\mathrm{He}, \mathrm{C}$, and $\mathrm{N})$ and compositional fingerprints. Geochim Cosmochim Acta 63:3653-3671. https://doi. org/10.1016/S0016-7037(99)00187-8 